\title{
Ortaokul Öğrencilerinin Eğitiminde Seçmeli Derslerin Yeri
}

\author{
DOI: $10.26466 /$ opus. 359758 \\ Mustafa Durmuşçelebi ${ }^{*}$ Burcu Mertoğlu ${ }^{* *}$ \\ ${ }^{*}$ Doç. Dr., Erciyes Üniversitesi, Eğitim Fakültesi, Melikgazi / Kayseri / Türkiye \\ E-Posta: $\underline{\text { mdcelebi@erciyes.edu.tr }}$ \\ ORCID: 0000-0002-0325-7528 \\ **Öğretmen, Milli Eğitim Bakanlığı, Pınarbaşı/Kayseri/Türkiye \\ E-Posta: burcumertoglu33@gmail.com \\ ORCID: 0000-0001-5399-6217
}

Öz

$B u$ araştırmanın amacl, ortaokullardaki seçmeli ders uygulamasını öğretmenler görüşlerine göre değerlendirmektir. Araştırmanın amaçlarına uygun olarak öğretmenlerin seçmeli derslere ilişkin genel görüşlerine, seçmeli derslerin okullarda uygulanma sürecine, seçmeli derslerin amaçları, içeriğ̈i, öğrenme-öğretme ve değerlendirme durumlarına ilişkin görüşleri alınmıştır. Bu görüşlerin cinsiyet, kıdem ve branşa göre anlaml farklılık gösterip göstermedikleri incelenmiştir. Araştırmanın evrenini 2016-2017 eğitim öğretim yılında Kayseri ili ve ilçelerinde görev yapmakta olan, ortaokul öğretmenleri oluşturmaktadır. Kayseri'de ortaokullarda çalışan 358 öğretmen araştırmanın örneklem grubunda yer almaktadır. Araştırmada Uysal (2015) tarafindan geliştirilen "Ortaokul Seçmeli Dersler Uygulamasının Öğretmen Görüşlerine Göre Değerlendirilmesi" anketi kullanılmıştır. Anket üç bölümden oluşmuştur. Birinci kısımda kişisel bilgiler, ikinci kısımda seçmeli derslerle ilgili bilgilere, üçüncü kısımda ise; seçmeli derslerin amaçları, içeriği öğrenme öğretme durumları ve değerlendirme boyutlarına yönelik maddeler vardır. Araştırma sonuçlarına bakıldığııda, okutulan seçmeli derslerin okul idaresi tarafindan belirlendiği görülmüş̧ür. Seçmeli derslerle ilgili okulun fiziksel imkânlarının yeterli olmadığı ve okulda bulunan öğretmenlere göre ders seçimi yapıldığı sonucuna varılmıştır. Öğretmenler, seçmeli dersleri faydalı ve gerekli bulduklarım belirtmişlerdir. Araştırmaya katılan öğretmenler, seçmeli ders seçim sürecinde veli bilgilendirmesi yapılmadığı ve öğrencilerin rehberlik servisinden yardım almadıkların belirtmişlerdir. Öğretmenlerimiz seçmeli derslerin amacına ulaştı̆̆ın belirtmelerine karşın aynı zamanda zorunlu derslere takviye gibi işlendiğini de dile getirmişlerdir.

Anahtar Kelimeler: Seçmeli Ders, Ortaokul Öğretim programı, Ĕ̆itim, Program değerlendirme, Öğretmen görüşü

OPUS (c) Uluslararası Toplum Araştırmaları Dergisi-International Journal of Society Researches ISSN:2528-9527 E-ISSN : 2528-9535

http://opusjournal.net 


\title{
Importance of Elective Course in Middle School Ed- ucation
}

\begin{abstract}
Aim of this search is that practise of elective course in middle school is evaluated according to teacher's opinions. Teacher's opinions were receiced about general opinions related to elective course, process of course in middle school, aim, content, learning, teaching and evaluation of elective cours. These opinions were examined whether they chenge according to gender, seniority, branch. Search consist of middle school teachers who study in Kayseri province and this country in 2016-2017. 358 teacher attend to this search. "Practise of elective course in middle school according to teacher's assessment" questionnaire improved by Uysal (2015) was used. Questionnaire consists of three sections. There is personal information in first section, there is information about elective course in second section and there are aim of course, learning and teaching situations and evaluation in third section. Result of search is that elective course in middle school is determined by school administration. School's physical conditions are not enough and choosing elective course is up to teacher. Teachers have stated that elective courses are useful and necessary. Parents of students aren't informed and counseling service doesn't help students in chosing elective courses. Teachers who attended to search have also stated that although elective courses succeed, these courses are like addition to compulsary lessons.
\end{abstract}

Keywords: Elective Course, Program of Secondary education, Education, Program Evaluation, Teacher Opinion 


\section{Giriş}

Bir ülkenin her yönden kalkınmasının en önemli unsurlarından birisi bireydir. Bireyin sahip olduğu beceri ve yetenekleri bularak, onları ilgi ve yeteneklerine göre yetiştirmek, böylece hem bireyin hem toplumun kalkınmasına katkıda bulunmak eğitim sisteminin en stratejik işlevidir. $\mathrm{Bu}$ işlevini yerine getirirken sistemin sürekli göz önünde bulundurması gereken nokta ise her bireyin ayrı bir dünya olduğudur. Türk eğitim sisteminin temel amaçları arasında bu durum özellikle vurgulanmıştır. Söz konusu vurgu Millî Eğitim Temel Kanunu'nun 3. Maddesinde şu şekilde yer almaktadır:

Madde 3. Illgi, istidat ve kabiliyetlerini geliştirerek gerekli bilgi, beceri, davranışlar ve birlikte iş görme alışkanlığı kazandırmak suretiyle hayata hazırlamak ve onların, kendilerini mutlu kılacak ve toplumun mutluluğuna katkıda bulunacak bir meslek sahibi olmaların sağlamak; Böylece bir yandan Türk vatandaşlarmın ve Türk toplumunun refah ve mutluluğunu artırmak; öte yandan milli birlik ve bütünlük içinde iktisadi, sosyal ve kültürel kalkınmayı desteklemek ve hızlandırmak ve nihayet Türk Milletini çă̆daş uygarlı̆̆ın yapıcı, yaratıcı, seçkin bir ortă̆ı yapmaktır (MEB, 2017).

Eğitim bireyleri, yaşam becerileriyle donatabilecek, onları hızla değişen dünyaya ve geleceğe hazırlayacak olan bir araçtır. Eğitim sisteminin temeli olan okullardan beklenen, yaşadığımız çağı irdeleyerek, toplumların gereksinim duydukları nitelikleri ortaya koyup bu nitelikleri kazandırarak bireyleri çok yönlü olarak eğitmektir. Dünyada bilim ve teknolojideki hızlı değişim, insanların yaşam biçimlerini, toplumun yapısın, gereksinimlerini, ihtiyaç duyulan insan niteliklerini etkilemekte ve daha donanımlı, çok yönlü, değişik bilgi ve becerilere sahip bireylerin yetiştirilmesini zorlaaktadır. Okullardan beklenen, yaşadığımız çağı irdeleyerek, toplumların gereksinim duydukları nitelikleri ortaya koyup bu nitelikleri kazandırarak bireyleri çok yönlü olarak eğitmektir. Bu zorunluluk okullarımızın eğitim programlarında da sürekli yeniliği ve dinamikliği beraberinde getirmektedir. Nitelikli insan gücüne sahip olmak için öğrencilerin daha iyi öğrenebileceği ortam ve fırsatlar sunarak zorunlu derslerle birlikte demokratik anlayışla bireylerin ilgi ve 
yeteneklerine uygun tercih yapabildikleri seçmeli ders uygulaması bu amaca hizmet etmektedir.

Son yıllarda dünyadaki genel eğilim, çocukların temel eğitimden itibaren disiplinler arası bir anlayışla yetiştirilmesi yönündedir. Eğitim fakültelerinin yeniden yapılandırılması sürecinde bölümlerin birleştirilmeleri, özellikle ders isim ve içeriklerinin değiştirilmesi, lisansüstü eğitim programlarında zorunlu derslerin sınırlı tutularak seçmeli derslerin sayı ve türlerinin artırılması bu anlayışın bir ürünü olarak görülebilir. Genelde mesleki gelişim ve ekonomik verimlilik amaçlarına ă̆ırlık verilen günümüz üniversite eğitiminde akademik, kişisel ve sosyal yönleriyle çok yönlü bir insan yetiştirilme üzerine yoğunlaşılmaktadır (Özgüven, 1989, s. 13-22). Özellikle ortaokul ve lise döneminde artık duymaya başladığımız FETEMM (Fen, Teknoloji, Mühendislik, Matematik) eğitimi gibi kavramlar aslında disiplinler arası ders mantı̆̆ının sistemleştirilmiş bir biçimi sayılabilir.

"Zorunlu dersler dışında öğrenciye alacağı dersleri seçme imkânı vermek günümüz demokratik anlayışına uygun bir yaklaşımdır. Öğrenciye değişik alternatifler sunmak öğrencinin okula karşı olumlu tutumlar geliştirmesine de yardımcı olacaktır... Seçmeli dersler, okul programlarının ayrılmaz bir parçası olarak öğrencilerin gelişimlerine destek olmaktadır. Seçmeli dersler öğrencilerin bilişsel (bilgi, beceri), duyuşsal (ilgi, tutum) ve sosyal gelişimlerine katkı sağlamaktadır" (EARGED, Seçmeli derslerin seçim kriterlerinin değerlendirilmesi araştırması, 2008).

Seçmeli dersleri iki başlıkta ele almak mümkündür; öğrencinin ilgi ve yeteneklerini tespit etmeye, çevresini tanımaya yarayan araştırma merkezli seçmeli dersler ve bir alanda yoğunlaşmaya dönük olarak tercih edilen seçmeli dersler (Frank, 1976). Daha çok Avrupa ülkelerinde rastlanan seçmeli ders uygulaması ise toplumsal olarak sorunlu bazı alanlardaki derslerin verilmesi şeklinde olmaktadır. Bu dersler ise genellikle din, tarih ve dil dersleridir (Taş, 2004). Türkiye'deki uygulamalara bakıldığında, her iki türde de seçmeli ders seçmek mümkün görülmektedir. Bu bağlamda seçmeli derslerin türünün belirlenmesi aşamasında bireysel, toplumsal ve kültürel gereksinimlerin dikkate alındığı söylenebilir. Eğitim sürecinin ilk basamaklarında birinci türden seçmeli dersleri, mesleki eğitim sürecinde ise ikinci türden seçmeli dersleri tercih etmek daha doğru görülmektedir. Yapılan araştırmalarda elde 
edilen bulgulara göre üniversite öğrencileri ders tercihlerini, daha çok iş yaşamlarına katkıda bulunmasına, kredi doldurma durumlarına ve en önemlisi de öğretim üyesi hakkındaki görüşlerine göre belirlemektedir. Öğrencilerin öğretim üyesi hakkındaki görüşleri seçmeli ders tercihini birinci derecede etkilemektedir. Buna karşıllk akademik beklenti amacıyla seçmeli ders tercihi en son sırada yer almaktadır (Tezcan, 2008).

Türkiye'de 30.03.2012 tarihinde kabul edilen Temel Eğitim Kanunu ile 12 yıllık zorunlu kademeli eğitim sistemi kabul edilmiş ve 2012-2013 eğitim öğretim yılında uygulamaya konmuştur. Yapılan değişiklikle ilk, orta ve lise eğitimi dörder yıl olarak belirlenmiş ve özellikle seçmeli ders saati ve çeşidi artırılmıştır. Seçmeli derslerin "öğrencileri hayata hazırlaması, ilgi ve yeteneklerini ortaya çıkarmada faydalı olması, okul programlarının ayrılmaz bir parçası olarak öğrencilerin gelişimlerine destek olması, ayrıca bilişsel (bilgi, beceri), duyuşsal (ilgi, tutum) ve sosyal gelişimlerine katkı sağlaması beklenmektedir. Hızla değişen dünyada öğrencilerin bu değişime ayak uydurabilmeleri için, yaşam becerilerinin de geliştirilmesi gerekmektedir. Zorunlu dersler dışında öğrenciye alacağı dersleri seçme imkânı vermek günümüz demokratik anlayışına uygun bir yaklaşımdır (EARGED, 2008). Bu bağlamda ortaokullarda toplam derslerin \% 17,1'ini seçmeli dersler oluşturmaktadır. Bu oran İmam Hatip ortaokullarında \% 4,9 ve liselerde ise türlerine göre \% 3,8 ile \% 36,4 arasında değişmektedir (ERG, 2016).

MEB Talim Terbiye Kurulu Başkanlığının 20.02.2017 tarih ve 10 nolu sayı ile aldığı karara göre 2017-18 eğitim öğretim yılından itibaren ortaokullarda uygulanmaya konan seçmeli dersler Tablo 1'de sinıflara göre dağıtılmıştır (MEB-TTKB, 2017).

Milli Eğitim Bakanlığı (MEB) tarafından yayımlanan seçmeli dersler genelgesinde, 2012 programına göre 5. sınıf öğrencileri için toplam 15 seçmeli ders belirlenmiş ve haftalık ders saati sayısına göre toplam 8 saat olacak şekilde ders seçebilecekleri ifade edilmiştir. 2017-18 eğitim öğretim yılında 1, 5 ve 8. sinıflarda uygulanmak üzere öğretim programları yenilenmiştir. Talim Terbiye Kurulu Başkanlığının 20.02.2017 tarihinde aldığ kararla seçmeli dersler ortaokullarda her sinıf için haftada 6 saate çıkarılmıştır (Tablo 1). Öğrencilerin taleplerine göre söz konusu ders saatleri ve sayısı artırılabilir. MEB tarafından belirlenen seçmeli dersler ile öğrencilerin akademik başarılarının yanında ilgi ve yeteneklerini keş- 
fetmeleri ve geliştirmelerinin amaçlandığı; bu nedenle seçmeli derslerin öğrencilerin ilgi, yetenek ve istekleri doğrultusunda velisinin de rehberliği ile öğrenci tarafından seçilmesi gerektiği belirtilmiştir (MEB-TTKB, 2017).

Tablo 1. Ortaokul seçmeli derslerin sürelerinin sınıflara göre dă̆ılımı

\begin{tabular}{|c|c|c|c|c|c|}
\hline \multicolumn{2}{|c|}{ SEÇMELİ DERSLER } & 5 & 6 & 7 & 8 \\
\hline \multirow{4}{*}{$\begin{array}{l}\text { Din, Ahlak } \\
\text { ve Değerler }\end{array}$} & Kur'an-1 Kerim (4) & 2 & 2 & 2 & 2 \\
\hline & Peygamberimizin Hayatı (4) & 2 & 2 & 2 & 2 \\
\hline & Temel Dini Bilgiler (2) & 2 & 2 & 2 & 2 \\
\hline & Okuma Becerileri (1) & 2 & 2 & & \\
\hline \multirow{3}{*}{$\begin{array}{l}\text { Dil ve An- } \\
\text { latım }\end{array}$} & Yazarlık ve Yazma Becerileri (4) & 2 & 2 & 2 & 2 \\
\hline & Yaşayan Diller ve Lehçeler (4) & 2 & 2 & 2 & 2 \\
\hline & İletişim ve Sunum Becerileri (1) & & & 2 & 2 \\
\hline Yabancı Dil & $\begin{array}{l}\text { Yabancı Dil (Bakanlar Kurulu Kararı } \\
\text { ile Kabul Edilen Diller) (4) }\end{array}$ & 2 & 2 & 2 & 2 \\
\hline \multirow{4}{*}{$\begin{array}{l}\text { Fen Bilim- } \\
\text { leri ve } \\
\text { Matematik }\end{array}$} & Bilim Uygulamaları (4) & 2 & 2 & 2 & 2 \\
\hline & Matematik Uygulamaları (4) & 2 & 2 & 2 & 2 \\
\hline & Çevre Ĕ̆itimi (1) & & & 2 & 2 \\
\hline & Bilişim Teknolojileri ve Yazılım (2) & & & 2 & 2 \\
\hline \multirow{5}{*}{$\begin{array}{l}\text { Sanat } \\
\text { Spor }\end{array}$} & $\begin{array}{l}\text { Görsel Sanatlar (Resim, Geleneksel } \\
\text { Sanatlar, Plastik Sanatlar vb.) (4) }\end{array}$ & $2 /(4)$ & $2 /(4)$ & $2 /(4)$ & $2 /(4)$ \\
\hline & Müzik (4) & $2 /(4)$ & $2 /(4)$ & $2 /(4)$ & $2 /(4)$ \\
\hline & $\begin{array}{l}\text { Spor ve Fizikî Etkinlikler (Alanlara } \\
\text { Göre Modüller Oluşturulacaktır) (4) }\end{array}$ & $2 /(4)$ & $2 /(4)$ & $2 /(4)$ & $2 /(4)$ \\
\hline & Drama (2) & 2 & 2 & & \\
\hline & Zekâ Oyunları (4) & 2 & 2 & 2 & 2 \\
\hline \multirow{5}{*}{$\begin{array}{l}\text { Sosyal } \\
\text { Bilimler }\end{array}$} & Halk Kültürü (4) & & & & \\
\hline & Kent Kültürü (1) & & & & \\
\hline & Medya Okuryazarlığı (1) & & & & \\
\hline & Hukuk ve Adalet (1) & & & & \\
\hline & Düşünme Eğitimi (2) & & & & \\
\hline \multicolumn{2}{|c|}{ Seçilebilecek Ders Saati Sayısı } & 6 & 6 & 6 & 6 \\
\hline
\end{tabular}

(*) Seçmeli derslerin kaç kez alınabileceğ i dersin adının yanında parantez içinde belirtilmiştir.

Yukarıda da belirtildiği üzere, seçmeli derslerin amacl, öğrencileri kendi ilgi ve yetenekleri doğrultusunda topluma kazandırmaktır. Bu yüzden seçmeli derslerin tercihinde tek ölçüt, öğrencinin ilgi ve yetenekleri olmalıdır. Ancak yapılan çalışmalar (Uysal, 2015; Eşbahoğlu2015; 
Pamuk ve Kiraz. 2016; Taş, 2004; Tezcan, 2008; Kaya, 2013; Karagözoğlu, 2015; Örs, Erdoğan ve Kipici, 2013; Sağır, 2015), seçmeli ders tercihlerinin ilgi ve yetenekleri dişında daha farklı sebeplerden ve imkânsızlıklardan kaynaklandığını göstermektedir. Söz konusu imkânsızlıklar yüzünden okullarda gerek yöneticiler gerekse öğretmenler seçmeli ders uygulamasina pek sicak bakmamakta, hem programin yapılmasinda hem de amacına hizmet etmesinde çeşitli sorunlarla karşılaşıldığı ifade edilmektedir. Yapılan bir çalışmada öğrencilerin en fazla $(\%$ 84,5) Matematik Uygulamalarına ilişkin dersleri, ikinci olarak $(\% 77,5)$ Kur'an-1 Kerim dersini ve \% 57,5 oranında da yabancı dil dersini seçtikleri görülmektedir. En az seçtikleri ders ise "Bilim Uygulamaları (\% 12)" ve “Okuma Becerileri (\% 12)" olmuştur (Karagözoğlu, 2015). Öğrencilerin seçmeli ders tercihlerini daha çok karşılaşacakları sınavlara göre belirledikleri, yani gelecek kaygısıyla seçtikleri, aslında kendi gelişimlerine katkıda bulunacak, düşünce dünyasını geliştirecek dersleri ise seçmedikleri ortaya çıkmıştır.

Görüldüğü gibi, Türkiye'deki uygulamaların seçmeli derslerin programlarda yer alma amaçlarına tam olarak hizmet ettiği söylenemez. Bazı okullarda öğretmen yetersizliği, öğrenci talebinin olmayışı ya da fiziki donanımın yetersiz olması, MEB tarafından hazırlanan programlarda yer almasına rağmen, birçok seçmeli dersin açılamamasına neden olmaktadır. Yapılan çalışmalar seçmeli derslerin hepsinin sayılan nedenlerden dolayı ya açılamadığı, açılanların ise çocuğun ilgi ve yeteneklerine göre değil, velilerin isteklerine göre seçmeli ders belirlendiğini göstermektedir. Söz konusu çalışmalarda gerek öğretmenler gerekse okul yöneticileri gereksiz seçmeli derslerin açılmaması gerektiğini, seçmeli dersler açlırken öğretmenlerin görüşlerinin alınması gerektiğini, okulun öğretmen ve fiziki donanım imkânlarına göre ders açılması gerektiğini ve bazı çalışmalarda da seçmeli derslerin amacına ulaşmadığını ifade etmişlerdir. Yapılan bu çalışmalarda öğrencilerin ilgi ve yeteneklerinden çok velilerin istekleri ve okulun hem fiziki hem de öğretmen kapasitesine göre ders seçimi yapıldığı ifade edilmektedir (Örs, Erdoğan ve Kipici, 2013; Çelik, Boz, Gümüş ve Taştan, 2013; Çelik, Yurdakul, Bozgeyikli ve Gümüş, 2017; Kaya, 2013; Cerit, Akgün, Yıldız ve Soysal, 2014; Sağır, 2015; Pamuk ve Kiraz, 2016). 
Seçmeli derslerin amacına ulaşılamamasının en büyük nedenlerinden birisi okullardaki nicel yetersizlikler ve ülkenin sinav sistemi olarak görülebilir. EARGED (2008)'in 1117 öğretmen ve 434 okul yöneticisini örneklem alarak yaptığı bir çalışmada, söz konusu öğretmen ve yöneticilerin görev yaptıkları okulların \% 65'inde Müzik, \% 56'sında Bilgisayar ve \% 51'inde resim öğretmeni bulunmamaktadır. Yine buna paralel olarak, okulların \% 82'sinde resim, \% 89'unda müzik odası bulunmamaktadır. Bu durum yukarıda belintilen olumsuz sonuçları yeterince açılamaktadır. Buna karşılık seçmeli dersler konusunda olumlu görüşlerin ortaya çıktığı araştırmalar da mevcuttur. Örs ve diğerlerinin(2013) yaptığ1 çalışmada, eğitim yöneticilerinin; "seçmeli ders yükü öğrencilere farklı ve alternatif ders alma imkânı sağlamaktadır", "seçmeli ders yükü, öğrencileri okulda daha fazla zaman geçirmek zorunda bırakmaktadır" ve "öğrencilerin seçmeli dersleri seçimlerinde ailelerinin daha etkili olduğu görülmektedir" ifadelerine katılıyorum düzeyinde görüş bildirmişlerdir.

Özellikle son on yıldır üzerinde önemle durulan seçmeli ders konusunun son durumunun ne olduğunu, okullardaki nicel gelişmelerin hangi boyutta olduğunu, öğrenci tercihlerinde bir değişiklik olup olmadığı, seçmeli ders tercihinde göz önünde bulundurulan ölçütlerdeki farklılıkları derslerin uygulayıcıları olan öğretmenlerin gözüyle gösterebilmesi açısından yapılan bu çalışmanın katkı sağlayabileceği düşünülmektedir.

$\mathrm{Bu}$ araştırmanın amacl, ortaokullardaki seçmeli derslerin öğretmen görüşlerine göre incelenmesidir.

Araştırmanın amacı doğrultusunda aşağıdaki sorulara yanıt aranmıştır:

1. Öğretmenlerin alan ve derslere göre seçmeli ders tercihi nasıl gerçekleşmektedir?

2. Araştırma yapılan okullardaki seçmeli ders uygulaması nasıl gerçekleşmektedir ve ders seçiminde kullanılan ölçütler nelerdir

3. Öğretmenlerin seçmeli derslere ve derslerin uygulanmasına yönelik görüşleri nelerdir? 
4. Öğretmenlerin seçmeli derslerin amaç, içerik, öğrenmeöğretme ve değerlendirme durumlarına ilişkin görüşleri nelerdir?

5. Öğretmenlerin seçmeli ders uygulamasına ilişkin görüşleri; cinsiyet ve branşlarına göre farklılık göstermekte midir?

\section{Yöntem}

\section{Araştırma Modeli}

Ortaokullarında görev yapan öğretmenlerin seçmeli dersler hakkındaki görüşlerini belirlemeyi amaçlayan bu araştırma tarama modelinde yapılan betimsel bir çalışmadır. Bilindiği gibi tarama modeli, "geçmişte ve hâlen var olan durumu var olduğu şekliyle betimlemeyi amaçlayan bir araştırma yaklaşımıdır" (Karasar, 2014). Bu araştırmada da ortaokullarda görev yapan öğretmenlerin seçmeli dersler ile ilgili görüşleri betimlenmeye çalışılmıştır.

\section{Evren ve Örneklem}

Araştırmanın evrenini Kayseri'de görev yapan ortaokul öğretmenleri oluşturmaktadır. "Kayseri'de 2016-2017 eğitim öğretim yılında toplam 296 ortaokulda 5465 öğretmen görev yapmaktadır" (Kayseri İl Milli Eğitim İstatistikleri, 2017). Söz konusu ortaokullar içerisinde 224 ortaokulda görev yapan 4735 öğretmen araştırmanın evrenini oluşturmaktadır. Bölge yatılı, imam hatip ve engelli ortaokullar araştırma kapsamı dişında tutulmuştur. Çalışmanın örneklem grubunu ise tesadüfi yöntemle belirlenen toplam 358 öğretmen oluşturmaktadır.

\section{Veri Toplama Araçları}

Araştırmada veri toplama aracı olarak Uysal (2015) tarafından geliştirilen “Ortaokullarda Seçmeli Ders Uygulamasına İlişkin Öğretmen Görüş Anketi” kullanılmıştır. Anketin maddelerinin çalışmanın konusu ve amacına uygun olup olmadığının belirlenmesi için 2 program geliştirme uzmanı, 3 ölçme değerlendirme uzmanı ve 1 çocuk gelişim uzmanı olmak üzere toplam 6 kişinin görüşlerine sunulmuştur. Uz- 
manlardan gelen görüşler doğrultusunda very toplama aracındaki eksiklikler giderilmiş, bazı maddelerin ifadeleri değiştirilerek sadeleştirilmiştir. Uzman görüşleri doğrultusunda maddelerde gerekli düzenlemeler yapılmış ve öğretmen anketinde 37 maddenin yer almasına karar verilmiştir. Uysal'ın yaptığı geçerlilik çalışması dışında bu araştırmada ayrı bir geçerlik çalışması yapılmaması bu araştırmanın sinırlılıkları arasındadır.

Araştırmanın 37 maddesi kendi içerisinde, 10 madde öğretmenlerin genel olarak seçmeli ders uygulamaları hakkındaki görüşleri, 7 madde kendi okullarındaki seçmeli ders uygulama biçimine ilişkin görüşleri ve 20 madde seçmeli derslerin öğretim programın boyutlarına (amaç, içerik, öğrenme öğretme ve değerlendirme) göre değerlendirilmesini içeren görüşler olmak üzere üç bölümde ele alınmaktadır.

\section{Verilerin Analiz Edilmesi}

Araştırmada toplanan veriler bilgisayara işlenmiş ve uygun bir istatistik programında analizleri yapılmıştır. Verilerin çözümlenmesinde araştırmanın alt problemlerine ve modeline uygun olarak frekans, yüzde ve ortalama gibi betimsel istatistik tekniklerinden yararlanılmıştır. $\mathrm{Bu}$ bağlamda öğrencilerin seçmeli ders tercihleri, okullardaki uygulamalar, kullanılan ölçütler ve seçmeli derslerin uygulanmasına ilişkin betimlemelerde yüzde, frekans ve ortalama gibi betimsel istatistik tekniklerinden, cinsiyet kıdem branş değişkenlerine göre farklılık gösterip göstermediğine ilişkin betimlemelerde de ki kare testinden yararlanılmıştır.

\section{Bulgular}

Bu bölümde araştırmanın alt problemleri doğrultusunda bulgulara yer verilmiştir. Öncelikle araştırmaya katılan öğretmenlerin cinsiyet ve kıdemlerine göre dağılımına Tablo 2' de yer verilmektedir.

Tablo 2 incelendiğinde, örneklem grubuna giren öğretmenlerin çoğunluğunun kadın $(\% 58,7)$ ve $1-5$ yıl arası kıdeme sahip $(\% 43,0)$ öğretmenlerden oluştuğu görülmektedir. 21 yıl ve üzeri kıdeme sahip öğretmenler $(\% 3,9)$ araştırmaya en az katılan öğretmen grubu olarak dikkat çekmektedir. 
Tablo 2. Öğretmenlerin cinsiyet ve mesleki kıdemlerine göre dă̆ılımı

\section{Mesleki Kidem}

\begin{tabular}{|c|c|c|c|c|c|c|c|c|c|c|c|c|}
\hline & \multicolumn{2}{|c|}{ 1-5 Yil } & \multicolumn{2}{|c|}{ 6-10 Y 11} & \multicolumn{2}{|c|}{ 11-15 Y1l } & \multicolumn{2}{|c|}{$16-20 Y_{1}$} & \multicolumn{3}{|c|}{$21 Y_{1} l$ üst } & \multirow{2}{*}{$\begin{array}{c}\text { Toplam } \\
\%\end{array}$} \\
\hline & $\mathrm{f}$ & $\%$ & $\mathrm{f}$ & $\%$ & $\mathrm{~F}$ & $\%$ & $\mathrm{~F}$ & $\%$ & $\mathrm{f}$ & $\%$ & $\mathrm{f}$ & \\
\hline CinsiyetKadın & 104 & 49,5 & 42 & 20,0 & 30 & 14,3 & 26 & 12,4 & 8 & 3,8 & 210 & 58,7 \\
\hline Erkek & 50 & 33,8 & 50 & 33,8 & 30 & 20,3 & 12 & 8,1 & 6 & 4,1 & 148 & 41,3 \\
\hline Toplam & 154 & 43,0 & 92 & 25,7 & 60 & 16,8 & 38 & 10,6 & 14 & 3,9 & 358 & 100,0 \\
\hline
\end{tabular}

Araştırmanın birinci alt problemi branş ve derslere göre seçmeli ders tercihinin nasıl olduğuna ilişkindir. Ancak burada hangi dersin daha çok tercih edildiği, örneklem kapsamında derse giren öğretmenlerin seçmeli ders olarak girdikleri alana göre belirlenmiştir. Tablo 3'te araştırmada görüş bildiren öğretmenlerin girdikleri seçmeli dersler ve bu derslerin ilgili olduğu alanlara göre dağılımı yer almaktadır.

Tablo 3. Seçmeli ders tercihlerinin alan ve derslere göre dağılımı

\begin{tabular}{|c|c|c|c|c|c|c|c|c|c|c|c|c|}
\hline \multirow{2}{*}{$\begin{array}{l}\text { Seçmeli ders alan- } \\
\text { ları ve tercih edilen } \\
\text { dersler }\end{array}$} & \multicolumn{2}{|c|}{$\begin{array}{l}\text { Din, } \\
\text { Ahlak ve } \\
\text { Değerler }\end{array}$} & \multicolumn{2}{|c|}{$\begin{array}{l}\text { Dil ve } \\
\text { Anlatım }\end{array}$} & \multicolumn{2}{|c|}{$\begin{array}{l}\text { Yabanc1 } \\
\text { dil }\end{array}$} & \multicolumn{2}{|c|}{$\begin{array}{lr}\text { Fen } & \text { Bilim- } \\
\text { leri } & \text { ve } \\
\text { Matematik }\end{array}$} & \multicolumn{2}{|c|}{$\begin{array}{l}\text { Sanat } \\
\text { ve Spor }\end{array}$} & \multicolumn{2}{|c|}{$\begin{array}{l}\text { Sosyal } \\
\text { Bilimler }\end{array}$} \\
\hline & $\mathrm{f}$ & $\%$ & $\mathrm{f}$ & $\%$ & $\mathrm{f}$ & $\%$ & $\mathrm{f}$ & $\%$ & $\mathrm{f}$ & $\%$ & $\mathrm{f}$ & $\%$ \\
\hline Kur'an-1 Kerim & 16 & 4,5 & & & & & & & & & & \\
\hline $\begin{array}{l}\text { Peygamberimizin } \\
\text { Hayatı }\end{array}$ & 2 & 0,6 & & & & & & & & & & \\
\hline Okuma Becerileri & & & 13 & 3,6 & & & & & & & & \\
\hline $\begin{array}{l}\text { Yazarlık ve Yazma } \\
\text { Becerileri }\end{array}$ & & & 10 & 2,8 & & & & & & & & \\
\hline $\begin{array}{l}\text { Yaşayan Diller ve } \\
\text { Lehçeler }\end{array}$ & & & 2 & 0,6 & & & & & & & & \\
\hline $\begin{array}{l}\text { İletişim ve Sunum } \\
\text { Becerileri }\end{array}$ & & & 2 & 0,6 & & & & & & & & \\
\hline Yabancı Dil & & & & & 18 & 5,0 & & & & & & \\
\hline $\begin{array}{l}\text { Bilim Uygulama- } \\
\text { ları }\end{array}$ & & & & & & & 6 & 1,7 & & & & \\
\hline $\begin{array}{l}\text { Matematik Uygu- } \\
\text { lamaları } \\
\text { Bilişim }\end{array}$ & & & & & & & 184 & 51,4 & & & & \\
\hline $\begin{array}{l}\text { Teknolojileri ve } \\
\text { Yazılım }\end{array}$ & & & & & & & 4 & 1,1 & & & & \\
\hline Zeka Oyunları & & & & & & & & & 7 & 2,0 & & \\
\hline $\begin{array}{l}\text { Medya Okurya- } \\
\text { zarlığ } 1\end{array}$ & & & & & & & & & & & 2 & 0,6 \\
\hline $\begin{array}{l}\text { Derse girmeyen } \\
\text { öğretmen }\end{array}$ & 92( & o 25,7$)$ & & & & & & & & & & \\
\hline Toplam & 358 & $\% 100)$ & & & & & & & & & & \\
\hline
\end{tabular}


Tablo 3 incelendiğinde, örneklem kapsamındaki öğretmenlerin en fazla $(\% 51,4)$ Matematik Uygulamaları dersine giren öğretmenler olduğu dikkat çekmektedir. Matematik dersini sırayla Yabancı dil (\%5), Kur'an-1 Kerim $(\% 4,5)$ ve Okuma Becerileri $(\% 3,6)$ dersine giren öğretmenler izlemektedir. Tabloda öğretmenlerin girdikleri dersler incelendiğinde; MEB tarafından belirlenen 23 çeşit seçmeli dersin 12 tanesi açılabilmiş, öğrencilerin liseye geçişte ve üniversite sınavında en fazla işlerine yarayacak dersleri tercih ettikleri ortaya çıkmıştır. Tabloya göre, en az Peygamberimizin Hayatı $(\% 0,6)$, Yaşayan Diller ve Lehçeler $(\% 0,6)$, İletişim ve Sunum Becerileri $(\% 0,6)$ ve Medya Okuryazarlığ $(\% 0,6)$ dersine giren öğretmenlerin dersleri tercih edilmiştir. Araştırmaya katılan öğretmenlerin \% 25,7'si de herhangi bir seçmeli derse girmediklerini belirtmişlerdir.

Araştırmanın ikinci alt problemi, örneklem grubundaki okullardaki seçmeli ders uygulamasının nasıl olduğu, seçmeli derslerin açılmasına kimlerin karar verdiği ve kullanılan ölçütlerin ne olduğuna ilişkindir. Araştırma kapsamındaki okullarda seçmeli dersleri kimlerin belirlediğine ilişkin veriler Tablo 4 'te yer almaktadır.

Tablo 4. Seçmeli derslerin açılmasında etkili olan bireyler ve kullanılan ölçütler

\begin{tabular}{|c|c|c|c|c|}
\hline $\begin{array}{l}\text { Seçmeli dersin açılmasını belir- } \\
\text { leyenler }\end{array}$ & $\mathrm{f}$ & $\%$ & Ölçütler & $\mathrm{f}$ \\
\hline Okul İdaresi & 138 & 38,5 & Öğretmenlerin istekleri & 59 \\
\hline Öğretmenler kurulu & 6 & 1,7 & Ö̆̆roncilorin isteklori & 157 \\
\hline Veliler & 16 & 4,5 & Ugrencilerin istekieri & $15 \%$ \\
\hline Öğrenciler & 22 & 6,1 & & \\
\hline $\begin{array}{l}\text { Okul İdaresi, Öğrenciler ve } \\
\text { Veliler }\end{array}$ & 75 & 20,9 & $\begin{array}{l}\text { Derse girecek ogretmenin } \\
\text { olması }\end{array}$ & 119 \\
\hline Okul İdaresi ve Veliler & 10 & 2,8 & & \\
\hline Okul İdaresi ve Öğrenciler & 30 & 8,4 & Velilerin istekleri & 115 \\
\hline Veliler ve Öğrenciler & 24 & 6,7 & & \\
\hline $\begin{array}{l}\text { Öğretmenler Kurulu ve Öğren- } \\
\text { ciler }\end{array}$ & 6 & 1,7 & Okulun fiziksel olanakları & 134 \\
\hline $\begin{array}{l}\text { Okul İdaresi ve Öğretmenler } \\
\text { Kurulu }\end{array}$ & 31 & 8,7 & Okul yönetiminin istekleri & 13 \\
\hline Toplam & 358 & 100,0 & & \\
\hline
\end{tabular}

Seçmeli dersler öğrencileri daha çok hedef, ilgi ve istek ve yetenekleri doğrultusunda geliştirmek amacıyla programlara konmuştur. Ancak 
Tablo 4 incelendiğinde, okullarımızda seçmeli derslerin üçte birinden fazlasının $(\% 38,5)$ okul idaresi tarafından belirlendiği görülmektedir. Bu orana \%8,7 okul idaresi ve öğretmen, \% 1,7 öğretmenler kurulu ve \%2,8 okul idaresi ve velilerin katkısı düşünüldüğünde, toplamda öğrencilerin belirlemesi gereken seçmeli ders tercihini \%51,7 oranında öğrenci dışındaki kişiler belirlemektedir. Öğrencilerin sadece \%6,1'i derslerini kendileri seçmekte, $\% 20,9^{\prime} \mathrm{u}$ okul idaresi ve aileleriyle birlikte belirlemektedir. Ailelerine danışarak seçmeli ders tercihini yapan öğrenci ise $\% 6,7$ civarındadır. Bu tabloya göre programa seçmeli ders koyma hedefinin \% 50 dolaylarında gerçekleştirildiği görülmektedir.

Öğretmenlere seçmeli ders belirlerken hangi ölçütlerin kullanıldığı sorulduğunda; öğretmenler en fazla (157) öğrencilerin isteklerinin ölçüt alındığını vurgulamışlardır. Okulun fiziksel olanaklarının belirleyici etken olduğunu söyleyen öğretmen sayısı 134'tür. Bunu sırayla derse girecek öğretmenin olması (119) ve veli istekleri (115) izlemektedir. Seçmeli ders açılmasında en az dikkate alınan konu ise okul yönetiminin istekleri (13) olmuştur.

Araştırmanın üçüncü alt problemi, öğretmenlerin genel olarak seçmeli ders uygulaması ve bu derslerin uygulama biçimlerine ilişkin ne düşündükleri ile ilgilidir. Tablo 5 'te öğretmenlerin genel anlamda seçmeli ders uygulamasına ilişkin görüşlerine ait veriler yer almaktadır.

Tablo 5. Öğretmenlerin seçmeli ders uygulamasına ilişkin genel görüşleri

\begin{tabular}{|c|c|c|c|c|c|c|c|c|c|c|c|c|}
\hline$\frac{0}{0}$ & $\begin{array}{l}\text { ÖĞRETMEN } \\
\text { GÖRÜŞLERİ }\end{array}$ & & 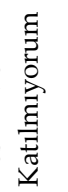 & & 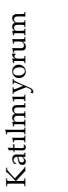 & & 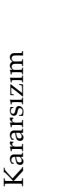 & & 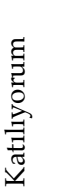 & & 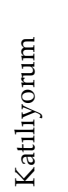 & $\overline{\mathrm{X}}$ \\
\hline$\sum^{\pi}$ & & $\mathrm{f}$ & $\%$ & $\mathrm{f}$ & $\%$ & $\mathrm{f}$ & $\%$ & $\mathrm{f}$ & $\%$ & $\mathrm{f}$ & $\%$ & \\
\hline 3 & $\begin{array}{l}\text { Seçmeli ders uygu- } \\
\text { lamasını gerekli } \\
\text { buluyorum. }\end{array}$ & 100 & 27,9 & 34 & 9,5 & 40 & 11,2 & 70 & 19,6 & 114 & 31,8 & 3,18 \\
\hline 4 & $\begin{array}{l}\text { Seçmeli ders uygu- } \\
\text { lamasını faydalı } \\
\text { buluyorum. }\end{array}$ & 96 & 26,8 & 52 & 14,5 & 48 & 13,4 & 70 & 19,6 & 92 & 25,7 & 3,03 \\
\hline 5 & $\begin{array}{l}\text { Girdiğim seçmeli } \\
\text { ders branşıma } \\
\text { uygundur. }\end{array}$ & 28 & 7,8 & 10 & 2,8 & 32 & 8,9 & 42 & 11,7 & 246 & 68,7 & 4,31 \\
\hline
\end{tabular}


Mustafa Durmuşçelebi - Burcu Mertoğlu

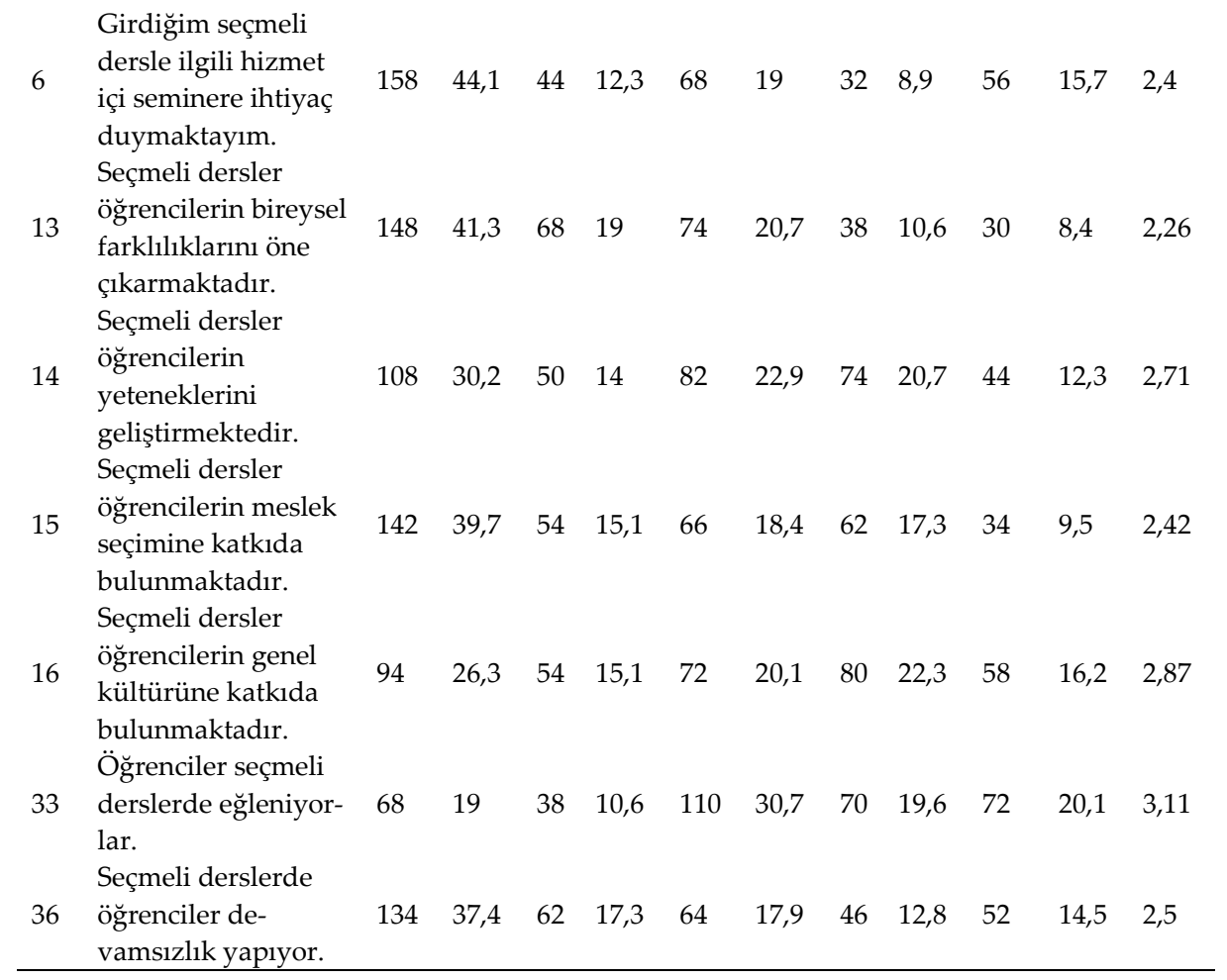

Tablo 5 incelendiğinde, öğretmenlerin en fazla (Katılıyorum + Tamamen katılıyorum $=\% 80,4)$ girdikleri derslerin branşlarına uygun olduğunu belirtmişlerdir. Yine tablodaki verilere göre öğretmenlerin \% 10 'undan fazlasının branşına uygun derse girmediği anlaşılmaktadır. Öğretmenlerin \% 8,9'u bu maddeye kararsızım şeklinde cevap vermemişlerdir. Öğretmenlerin girdikleri derslerin branşlarına uyup uymadığ konusunda kararsız kalmaları pek mümkün görülmediğinden, bu öğretmenlerin herhangi bir seçmeli derse girmeyen öğretmenler olduğu düşünülebilir. Öğretmenlerin yarısından fazlası $(\% 51,4)$ seçmeli ders uygulamasını gerekli görmekte (Madde 3), \%45,3'ü de faydalı bulduklarını (Madde 4) ifade etmişlerdir. Seçmeli derslerin gerekli olmadığını $(\% 37,4)$, kesinlikle faydalı bulmadığını $(\% 41,3)$ beliren öğretmen de azımsanamayacak kadar fazladır.

Seçmeli derslerin programlara konulmasının en önemli amaçlarından biri, bireysel farklılıkları belirleyerek, öğrencileri ilgi ve yeteneklerine 
göre uygun mesleklere yönlendirmektir. Ancak öğretmenlerin \%60,3’ü, seçmeli derslerin bireysel farklılıkları oraya çıkarmadığını (Madde 13), \%54,8'i de öğrencilerin meslek seçimine katkıda bulunmadığını (Madde 15) ifade etmiştir. Girdiği derslerde hizmet içi eğitime ihtiyaç duyan (Madde 6) öğretmen oranı ise sadece \%24,7'de kalmıştır.

Tablo 6 'da ise okullardaki seçmeli ders uygulamasına ilişkin öğretmen görüşlerine ait veriler bulunmaktadır.

\section{Tablo 6. Öğretmenlerin okullarındaki seçmeli ders uygulanmasına ilişkin görüşleri}

\begin{tabular}{|c|c|c|c|c|c|c|c|c|c|c|c|c|}
\hline$\frac{8}{8}$ & $\begin{array}{l}\text { ÖĞRETMEN } \\
\text { GÖRÜŞLERİ }\end{array}$ & & 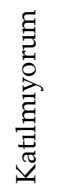 & 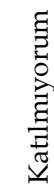 & & 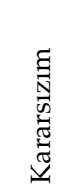 & & 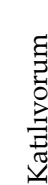 & & & 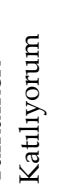 & $\overline{\mathrm{X}}$ \\
\hline & & $\mathrm{f}$ & $\%$ & $f^{2}$ & $\%$ & $\mathrm{f}$ & $\%$ & $\mathrm{f}$ & $\%$ & $\mathrm{f}$ & $\%$ & \\
\hline 1 & $\begin{array}{l}\text { Okulumuzda } \\
\text { seçmeli dersler } \\
\text { etkili bir şekilde } \\
\text { uygulanmaktadır. }\end{array}$ & 74 & 20,7 & 46 & 12,8 & 100 & 27,9 & 80 & 22,3 & 58 & 16,2 & 3,01 \\
\hline 7 & $\begin{array}{l}\text { Ogrencilere sunu- } \\
\text { lan seçmeli ders } \\
\text { türü yeterlidir. }\end{array}$ & 76 & 21,2 & 34 & 9,5 & 90 & 25,1 & 66 & 18,4 & 92 & 25,7 & 3,18 \\
\hline 8 & $\begin{array}{l}\text { Seçmeli ders seçim- } \\
\text { lerinden önce } \\
\text { öğrencilere dersler } \\
\text { tanitılmaktadır. }\end{array}$ & 140 & 39,1 & 60 & 16,8 & 46 & 12,8 & 38 & 10,6 & 74 & 20,7 & 2,57 \\
\hline 9 & $\begin{array}{l}\text { Okulumuzda } \\
\text { açılacak seçmeli } \\
\text { dersler velilere } \\
\text { duyurulmaktadır. }\end{array}$ & 76 & 21,2 & 42 & 11,7 & 48 & 13,4 & 72 & 20,1 & 120 & 33,5 & 3,33 \\
\hline 10 & $\begin{array}{l}\text { Öğrenciler ilgi ve } \\
\text { yetenekleri doğrul- } \\
\text { tusunda ders } \\
\text { seçmektedirler. }\end{array}$ & 148 & 41,3 & 86 & 24 & 44 & 12,3 & 36 & 10,1 & 44 & 12,3 & 2,28 \\
\hline 11 & $\begin{array}{l}\text { Öğrencilerin ders } \\
\text { seçiminde veliler } \\
\text { etkili olmaktadır. }\end{array}$ & 86 & 24 & 30 & 8,4 & 68 & 19 & 74 & 20,7 & 100 & 27,9 & 3,2 \\
\hline 12 & $\begin{array}{l}\text { Öğrenciler ders } \\
\text { seçerken okulun } \\
\text { rehberlik servisin- } \\
\text { den yardım almak- } \\
\text { tadırlar. }\end{array}$ & 190 & 53,1 & 62 & 17,3 & 64 & 17,9 & 20 & 5,6 & 22 & 6,1 & 1,94 \\
\hline
\end{tabular}


Tablo 6'daki veriler incelendiğinde, öğretmenlerin yarısından fazlasının $(\% 53,6)$ okullarında açlan derslerin velilere duyurulduğunu (Madde 9) ifade etmektedir. Öğrenci velisine hangi seçmeli derslerin açılacağının duyurulup duyurulmadığını bilmeyen öğretmen oranı ise \% 13,4'tür. Öğretmenlerin yarıya yakını $(\% 53,6)$, öğrencilerin ders seçiminde velilerin etkili olduğunu (Madde 11) düşünmektedir. Öğrencilere sunulan seçmeli ders türünün yeterli (Madde 7) olduğu konusunda öğretmenler bölünmüş durumda; öğretmenlerin \%32,4'ü "kesinlikle katılmıyorum ya da katılmıyorum", \%25,1'i "kararsızım" ve \%44,1'i de "katıllyorum ya da tamamen katılıyorum" seçeneğini işaretlemişlerdir.

Okullarda seçmeli ders konusunda öğrencilere katkı sağlaması beklenen bir başka birim de rehberlik birimidir. Ancak öğretmenlerin \%70,4'ü öğrencilerin seçmeli ders tercihlerini belirlemek için söz konusu birimden yararlanmadıklarını (Madde 12) düşünmektedir. Aynı şekilde öğrencilerin kendi ilgi ve yeteneklerine göre ders seçmediklerini (Madde 10) ifade eden öğretmen oranı \%65,3 bulunmuştur. Öğretmenlerin sadece \%22,4'ü öğrencilerin kendi ilgi ve yetenekleri doğrultusunda tercih yaptıklarını düşünmektedir.

Araştırmanın dördüncü alt problemine bağlı olarak öğretmenlere girdikleri seçmeli derslerin amaç, içerik, eğitim durumu ve değerlendirme süreçlerine ilişkin görüşleri sorulmuştur. Aşağıdaki tabloda (Tablo 7) öğretmenlerin seçmeli derslerin öğretim programlarına ilişkin görüşlerine ait veriler yer almaktadır.

Tablo 7. Öğretmenlerin seçmeli derslerin amaç, içerik, eğitim durumu ve değerlendirme boyutuna ilişkin görüşleri

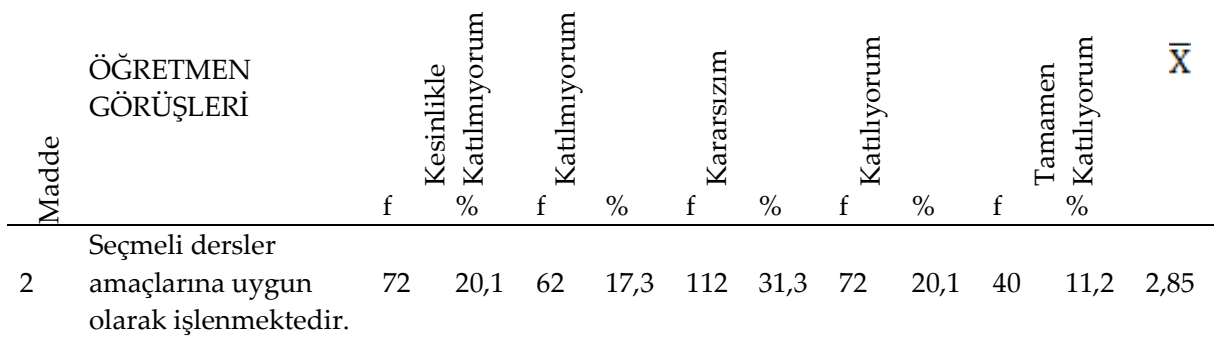


Seçmeli dersler zo-

runlu derslere takviye dersi gibi işlen-

$\begin{array}{lllllllllll}22 & 6,1 & 20 & 5,6 & 48 & 13,4 & 98 & 27,4 & 170 & 47,5 & 4,05\end{array}$

mektedir.

Girdiğim seçmeli

dersin öğretim pro-

gramını yeterli

$\begin{array}{lllllllllll}88 & 24,6 & 60 & 16,8 & 106 & 29,6 & 52 & 14,5 & 52 & 14,5 & 2,78\end{array}$

buluyorum.

Seçmeli derslerin

amaçlarına derslerin

öğretim programında

$\begin{array}{lllllllllll}44 & 12,3 & 60 & 16,8 & 124 & 34,6 & 90 & 25,1 & 40 & 11,2 & 3,06\end{array}$

yer verilmiştir.

Girdiğim seçmeli

dersin öğretim pro-

20 graminda yer alan

kazanımları açık ve

$\begin{array}{lllllllllll}72 & 20,1 & 60 & 16,8 & 118 & 33 & 62 & 17,3 & 46 & 12,8 & 2,86\end{array}$

anlaşılır buluyorum.

Girdiğim seçmeli

dersin öğretim ma-

teryalini/kitabını

$\begin{array}{lllllllllll}186 & 52 & 72 & 20,1 & 62 & 17,3 & 26 & 7,3 & 12 & 3,4 & 1,9\end{array}$

yeterli buluyorum.

Seçmeli derslerin

içerikleri günceldir.

$94 \quad 26,3 \quad 66$

Girdiğim seçmeli

dersin içeriğine

23 uygun kaynak bul-

makta zorluk çeki-

yorum.

Bazı seçmeli derslerin

içerikleri zorunlu

derslere paralel

30

$8,4 \quad 24$

6,7

106

$29,6 \quad 116 \quad 32,4 \quad 82$

$22,9 \quad 3,55$

olarak hazırlanmıştır.

Bazı seçmeli derslerin

25

içerikleri zorunlu

derslerin içerikleri ile

$30 \quad 8,4 \quad 26$

$26 \quad 7$

örtüşmektedir.

Seçmeli derslerin

etkili işlenebilmesi

için sınıf mevcutları

$\begin{array}{lllllllllll}20 & 5,6 & 14 & 3,9 & 40 & 11,2 & 48 & 13,4 & 236 & 65,9 & 4,3\end{array}$

azaltılmalıdır.

Seçmeli derslerin

işlenebilmesi için

okulun fiziksel

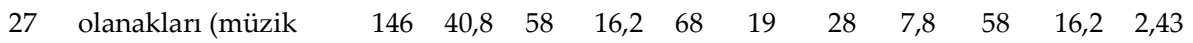

odas1, laboratuvar,

bilgisayar laboratu-

varl, vb.) yeterlidir. 
Mustafa Durmuşçelebi - Burcu Mertoğlu

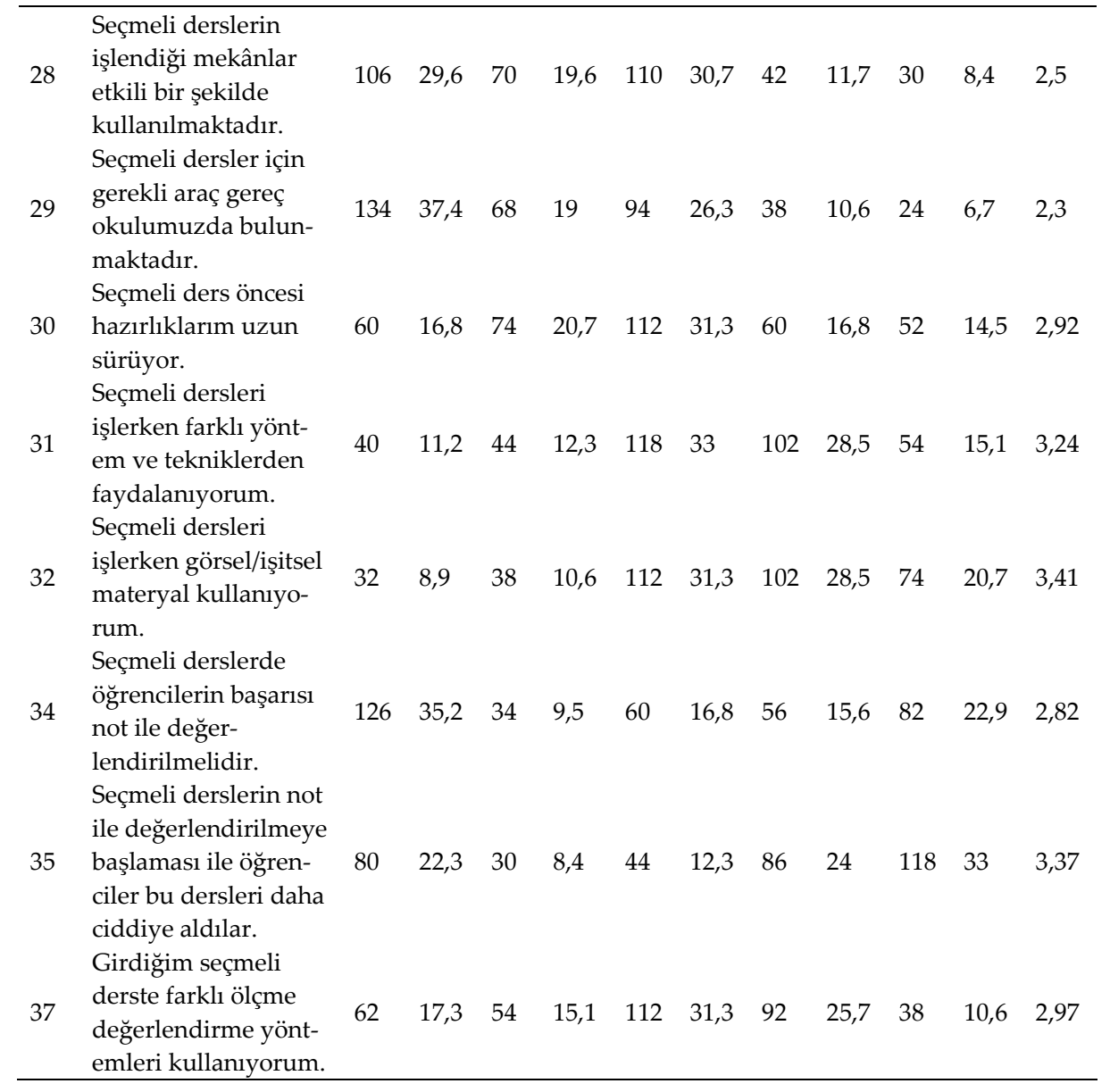

Tablo 7'deki veriler incelendiğinde, öğretmenlerin seçmeli derslerin okullarında işlenmesi sürecindeki karşılaşılan durumlara ilişkin görüşlerine ait veriler yer almaktadır. Buna göre öğretmenlerin büyük bir çoğunluğu $(\% 79,3)$ sınıfların kalabalık olmasından (Madde 26) şikâyetçi olmaktadır. Sadece öğretmenlerin \% 9,5'i sınıfların kalabalık olmadığını düşünmektedir, bu durumda araştırma kapsamındaki okulların çoğunluğunda sınıfların kalabalık olduğu ortaya çıkmıştır. Yine öğretmenlerin önemli bir bölümü $(\% 59,3)$ girdikleri seçmeli derslerin içeriğine uygun kaynak bulmakta zorlandıklarını (Madde 23), \%57'si ise, seçmeli derslerin not ile değerlendirilmesinin (Madde 35), öğrencilerin dersleri 
daha ciddiye almaları sonucunu doğurduğunu ifade etmişlerdir. Ancak öğrencilerin üçte biri $(\% 30,7)$ dersleri ciddiye aldığı konusunda aynı görüşte olmadıkları görülmektedir. Bu bölümün belki de en önemli bulgularından birisi, öğretmenlerin yarısından fazlasının $(\% 56,5)$ bazı seçmeli derslerin içerikleri ile zorunlu derslerin içeriklerinin örtüştüğü (Madde 25) görüşünü bildirmeleridir. Anketin 24. maddesi de aynı görüşü destekler nitelikte bulunmuştur. Bu durumda ortaya öğrencinin seçmeli dersleri ilgi alanlarına göre mi yoksa önemli gördükleri dersleri tekrar etmek amaciyla mı seçtikleri sorusu akla gelmektedir.

Öğretmenlerin önemli bir bölümü $(\% 72,1)$ girdikleri seçmeli derslerin öğretim araçlarını / materyallerini yeterli bulmadıklarını (Madde 21) ifade emişlerdir. Bu görüşü aynı zamanda 29. maddede belirtilen "okulumuzda seçmeli derslerle ilgili yeterli araç gereç bulunmaktadır" görüşüne katılmayan öğretmenler de $(\% 56,4)$ desteklemektedir. Seçmeli dersler için okullardaki donanımın yetersiz olduğu (\%57), bu derslerin işlendiği mekânların ekili bir şekilde kullanılmadığı $(\% 49,2)$, seçmeli derslerin yeterince güncel olmadığ $(\% 44,7)$ ve seçmeli derslerde öğrenci başarısının not ile değerlendirilmemesi gerektiği (\%44,7) konuları öğretmenlerin önemli bir bölümünün öğretim süreci ile ilgili ifade ettikleri konulardır.

Araştırmanın son alt problemi, okullarımızdaki seçmeli derslere ilişkin öğretmen görüşlerinin, onların cinsiyet, kıdem ve girdikleri ders alanlarına göre farklılıklarına ilişkindir. Tablo 8'de seçmeli ders uygulamasına ilişkin öğretmenlerin genel, uygulama ve sürece ilişkin görüşlerinin cinsiyet değişkenine göre farklılık durumlarına ait Ki-Kare testi bulguları yer almaktadır. Değişkenler arasında ilişkiye bakılan Ki-Kare testlerinde sadece anlamlı farklılık gösteren maddeler ele alınmıştır. 
Tablo 8. Öğretmenlerin seçmeli ders uygulamalarına ilişkin görüşlerinin cinsiyetlerine göre farklilıkları

\begin{tabular}{|c|c|c|c|c|c|c|c|c|c|c|}
\hline$\frac{⿱ \pi}{\frac{\pi}{0}}$ & ÖĞRETMEN GÖRÜŞLERİ & 蒿 & 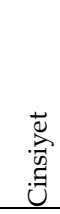 & $\mathrm{f}$ & 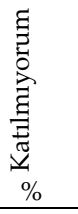 & $\mathrm{f}$ & 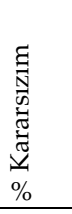 & $\mathrm{f}$ & 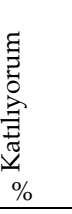 & $X^{2}$ \\
\hline \multirow{2}{*}{3} & \multirow{2}{*}{$\begin{array}{l}\text { Seçmeli ders uygulamasını } \\
\text { gerekli buluyorum. }\end{array}$} & \multirow{2}{*}{ Genel } & E & 42 & 28,4 & 18 & 12,2 & 88 & 59,5 & \multirow{2}{*}{0,01} \\
\hline & & & K & 92 & 43,8 & 22 & 10,5 & 96 & 45,7 & \\
\hline \multirow{2}{*}{4} & \multirow{2}{*}{$\begin{array}{l}\text { Seçmeli ders uygulamasını } \\
\text { faydalı buluyorum. }\end{array}$} & \multirow{2}{*}{ Genel } & E & 46 & 31,1 & 22 & 14,9 & 80 & 54,1 & \multirow{2}{*}{0,00} \\
\hline & & & K & 102 & 48,6 & 26 & 12,4 & 82 & 39,0 & \\
\hline \multirow{2}{*}{5} & \multirow{2}{*}{$\begin{array}{l}\text { Girdiğim seçmeli ders } \\
\text { branşıma uygundur. }\end{array}$} & \multirow{2}{*}{ Genel } & E & 20 & 13,5 & 18 & 12,2 & 110 & 74,3 & \multirow{2}{*}{0,05} \\
\hline & & & K & 18 & 8,6 & 14 & 6,7 & 178 & 84,8 & \\
\hline \multirow{2}{*}{14} & \multirow{2}{*}{$\begin{array}{l}\text { Seçmeli dersler öğrencilerin } \\
\text { yeteneklerini geliştirmekte- } \\
\text { dir. }\end{array}$} & \multirow{2}{*}{ Genel } & E & 66 & 44,6 & 22 & 14,9 & 60 & 40,5 & \multirow{2}{*}{0,00} \\
\hline & & & K & 92 & 43,8 & 60 & 28,6 & 58 & 27,6 & \\
\hline \multirow{2}{*}{7} & \multirow{2}{*}{$\begin{array}{l}\text { Öğrencilere sunulan seçmeli } \\
\text { ders türü yeterlidir. }\end{array}$} & \multirow{2}{*}{ Uyg } & E & 44 & 29,7 & 28 & 18,9 & 76 & 51,4 & \multirow{2}{*}{0,03} \\
\hline & & & K & 66 & 31,4 & 62 & 29,5 & 82 & 39,0 & \\
\hline \multirow{2}{*}{9} & \multirow{2}{*}{$\begin{array}{l}\text { Okulumuzda açılacak } \\
\text { seçmeli dersler velilere } \\
\text { duyurulmaktadır. }\end{array}$} & \multirow{2}{*}{ Uyg } & $\mathrm{E}$ & 56 & 37,8 & 24 & 16,2 & 68 & 45,9 & \multirow{2}{*}{0,05} \\
\hline & & & K & 62 & 29,5 & 24 & 11,4 & 124 & 59,0 & \\
\hline \multirow{2}{*}{11} & \multirow{2}{*}{$\begin{array}{l}\text { Öğgrencilerin ders seçiminde } \\
\text { veliler etkili olmaktadır. }\end{array}$} & \multirow{2}{*}{ Uyg } & E & 64 & 43,2 & 26 & 17,6 & 58 & 39,2 & \multirow{2}{*}{0,00} \\
\hline & & & K & 52 & 24,8 & 42 & 20,0 & 116 & 55,2 & \\
\hline \multirow[b]{2}{*}{27} & \multirow{2}{*}{$\begin{array}{l}\text { Seçmeli derslerin işlene- } \\
\text { bilmesi için okulun fiziksel } \\
\text { olanakları (müzik odası, } \\
\text { laboratuvar, bilgisayar } \\
\text { laboratuvarı, vb.) yeterlidir. }\end{array}$} & \multirow[b]{2}{*}{ Süreç } & E & 80 & 54,1 & 20 & 13,5 & 48 & 32,4 & \\
\hline & & & $\mathrm{K}$ & 124 & 59,0 & 48 & 22,9 & 38 & 18,1 & 0,00 \\
\hline & Seçmeli derslerin işlendiği & & E & 60 & 40,5 & 44 & 29,7 & 44 & 29,7 & \\
\hline 28 & $\begin{array}{l}\text { mekanlar etkilı bır şekılde } \\
\text { kullanılmaktadır. }\end{array}$ & Sureç & K & 116 & 55,2 & 66 & 31,4 & 28 & 13,3 & 0,00 \\
\hline 29 & $\begin{array}{l}\text { Seçmeli dersler için gerekli } \\
\text { arac gerec okulumuzda }\end{array}$ & Sürec & E & 80 & 54,1 & 30 & 20,3 & 38 & 25,7 & 00 \\
\hline & bulunmaktadır. & Juाटढ̧ & K & 122 & 58,1 & 64 & 30,5 & 24 & 11,4 & 0,00 \\
\hline 31 & Seçmeli dersleri işlerken & $\mathrm{Si}$ & E & 24 & 16,2 & 54 & 36,5 & 70 & 47,3 & \\
\hline 31 & $\begin{array}{l}\text { klerden faydalaniyorum. } \\
\text { klinom }\end{array}$ & Juाटढ̧ & K & 60 & 28,6 & 64 & 30,5 & 86 & 41,0 & 0,00 \\
\hline 34 & $\begin{array}{l}\text { Seçmeli derslerde öğrencil- } \\
\text { erin basarısı not ile değer- }\end{array}$ & Sürec & E & 78 & 52,7 & 14 & 9,5 & 56 & 37,8 & 0,00 \\
\hline & lendirilmelidir. & & K & 82 & 39,0 & 46 & 21,9 & 82 & 39,0 & \\
\hline
\end{tabular}


Tablo 8 incelendiğinde, seçmeli ders uygulamasına ilişkin toplamda 10 maddede özetlenmeye çalışılan öğretmen görüşlerinin 4 tanesinde öğretmenlerin cinsiyetlerine göre farklılık görülmektedir. Seçmeli dersleri gerekli ve yararlı bulan erkek öğretmenlerin oranı $(\% 59,5 ; \% 54,1)$ kadın öğretmenlerden fazla bulunmuştur. Erkek öğretmenlerin sadece \% 28,4'ü seçmeli ders uygulamasını gerekli bulmazken, bu oran kadın öğretmenlerde \%43,8 olarak ortaya çıkmıştır. Girdiğim seçmeli ders branşıma uygundur diyen kadın öğretmen oranı $(\% 84,8)$ erkek öğretmen oranından $(\% 74,3)$ daha yüksek bulunmuştur. Bu da erkek öğretmenlerin branşının dışında da seçmeli derslere girdiğini göstermektedir. Seçmeli dersler konusunda kadın öğretmenlerin çok iyimser olmadığını 14. maddede belirtilen "seçmeli dersler öğrencilerin yeteneklerini geliştirmektedir" görüşünde de görülmektedir. Kadın öğretmenlerin sadece \%27,6'sı seçmeli derslerin söz konusu katkısı olduğunu düşünürken, bu oran erkek öğretmenlerde $\% 40,5^{\prime}$ e ulaşmaktadır.

Öğretmenlerin çalıştıkları okullarındaki uygulama ile ilgili görüşleri toplam 7 maddede sorulmuş ve söz konusu 7 maddenin üçünde öğretmenlerin birbirlerinden farklı düşündükleri ortaya çıkmıştır. Okullarında açılan seçmeli derslerin türlerinin yeterli olduğunu ifade eden erkek öğretmen oranı $(\% 51,4)$ kadın öğretmenlerden $(\% 39,0)$ daha fazla bulunmuştur. Kadın öğretmenlerin üçte birinin bu konuda kararsız $(\% 29,5)$ kaldıkları görülmektedir. Kadın öğretmenlerin \%59,0'ı açılacak seçmeli derslerin velilere duyurulduğu, erkek öğretmenlerin ise $\% 37,8^{\prime}$ inin velilere duyurulmadığı görüşünde oldukları ortaya çıkmıştır. Yine kadın öğretmenlerin yarısından fazlası $(\% 55,2)$ açılacak derslerin velilere duyurulduğunu ifade etmiş, buna karşıllı erkek öğretmenlerin $\% 37,8$ 'i velilere bu derslerin duyurulmadığını söylemişlerdir.

Seçmeli derslerin öğretim programlarına, yani dersin işlenme sürecine ilişkin öğretmenlere toplamda 20 soru sorulmuş, ancak sadece 5 tanesinde öğretmenlerin görüşleri arasında farklılık ortaya çıkmıştır. Okulların fiziksel olanakları konusunda öğretmenlerin yarısından fazlası olumsuz bir tablo ortaya koymuştur. Kadın öğretmenlerin \%59, $0^{\prime} 1$ erkek öğretmenlerin ise \%54,1'i okullarında müzik odası, laboratuvar, bilgisayar laboratuvarı, vb. fiziksel koşullanın yeterli olmadığını belirtmişlerdir. Yine bunu destekler biçimde 29. maddede belirtilen ders araç gereci konusunda da, kadın öğretmenlerin \%58,1'i ile erkek öğretmenle- 
rin $\% 54,1^{\prime} i$ yetersizlikten bahsetmektedirler. Diğer maddelere de bakıldığında, kadın öğretmenlerin seçmeli derslerin uygulanma sürecinde erkeklerden daha kötümser düşündüğü görülmektedir. Erkek öğretmenler seçmeli dersleri işlerken daha farklı yöntemlerden yararlandıklarını $(\% 47,3)$ belirtirken, kadın öğretmenlerin \%28,6'sı farklı yöntemler kullanmadıklarını ifade etmişlerdir. Öğrenci performansını seçmeli derslerde de not ile değerlendirme görüşünü erkek öğretmenlerin $\% 52,7^{\prime}$ si desteklerken, kadın öğretmenlerin $\% 39,0$ ' 1 nottan yana görüş bildirmişlerdir.

Öğretmenlerin seçmeli ders konusundaki görüşlerinin kıdemlerine göre farklılıklarını ortaya çıkarmak amacıyla yapılan Ki-Kare testi bulguları Tablo 9'da yer almaktadır. Tablo 9, öğretmenlerin seçmeli ders uygulamasına ilişkin genel görüşleri (9-A), okullarındaki uygulama ile ilgili görüşleri (9-B) ve süreç boyutuna ilişkin görüşleri (9-C) olmak üzere 3 bölüme ayrılmıştır. Aşağıdaki tabloda (9-A) öğretmenlerin seçmeli ders uygulamasına genel olarak nasıl baktıklarını içeren veriler yer almaktadir.

Tablo 9-A. Öğretmenlerin seçmeli ders uygulamalarına ilişkin görüşlerinin kıdemlerine göre farklilikları

\begin{tabular}{|c|c|c|c|c|c|c|c|c|c|c|}
\hline $\begin{array}{l}\frac{0}{0} \\
\frac{\pi}{\pi} \\
\end{array}$ & $\begin{array}{l}\text { ÖĞRETMEN } \\
\text { GÖRÜŞLERİ }\end{array}$ & 苍 & $\frac{\Xi}{\mathbb{Z}}$ & $\mathrm{f}$ & 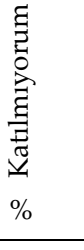 & $\mathrm{f}$ & 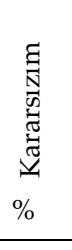 & $\mathrm{f}$ & 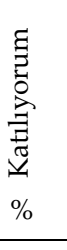 & \\
\hline \multirow{7}{*}{3} & \multirow{7}{*}{$\begin{array}{l}\text { Seçmeli ders uygu- } \\
\text { lamasını gerekli } \\
\text { buluyorum. }\end{array}$} & \multirow{7}{*}{ Genel } & SDY & 28 & 30,4 & 14 & 15,2 & 50 & 54,3 & \multirow{7}{*}{0,01} \\
\hline & & & DAD & 4 & 22,2 & 2 & 11,1 & 12 & 66,7 & \\
\hline & & & DA & 11 & 40,7 & 6 & 22,2 & 10 & 37,0 & \\
\hline & & & YD & 2 & 11,1 & 0 & 0,0 & 16 & 88,9 & \\
\hline & & & FBM & 82 & 42,3 & 18 & 9,3 & 94 & 48,5 & \\
\hline & & & SS & 5 & 71,4 & 0 & 0,0 & 2 & 28,6 & \\
\hline & & & $\mathrm{SB}$ & 2 & 100,0 & 0 & 0,0 & 0 & 0,0 & \\
\hline \multirow{3}{*}{4} & \multirow{3}{*}{$\begin{array}{l}\text { Seçmeli ders uygu- } \\
\text { lamasını faydalı } \\
\text { buluyorum. }\end{array}$} & \multirow{3}{*}{ Genel } & SDY & 40 & 43,5 & 12 & 13,0 & 40 & 43,5 & \multirow{3}{*}{0,00} \\
\hline & & & DAD & 2 & 11,1 & 2 & 11,1 & 14 & 77,8 & \\
\hline & & & DA & 11 & 40,7 & 4 & 14,8 & 12 & 44,4 & \\
\hline
\end{tabular}




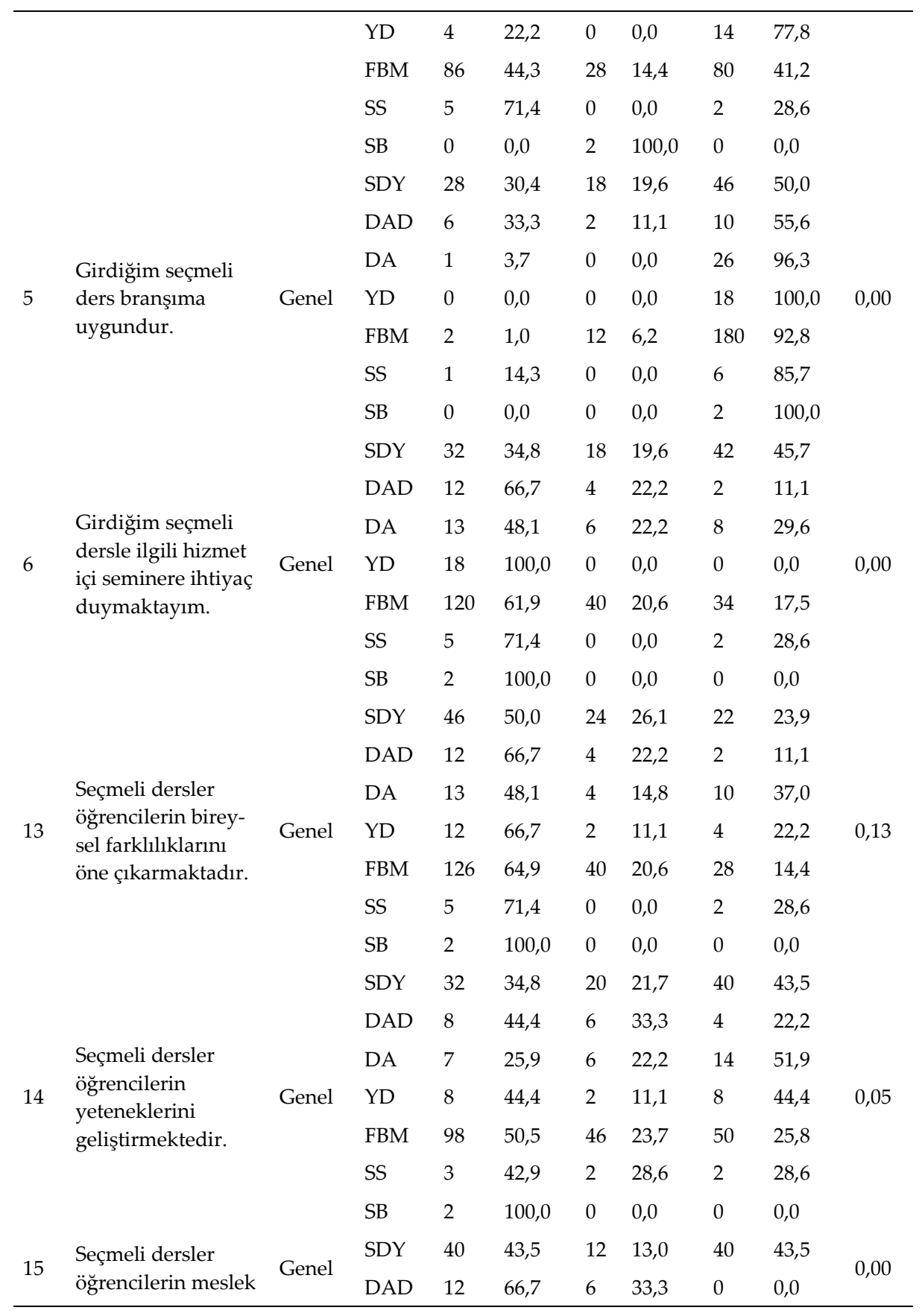




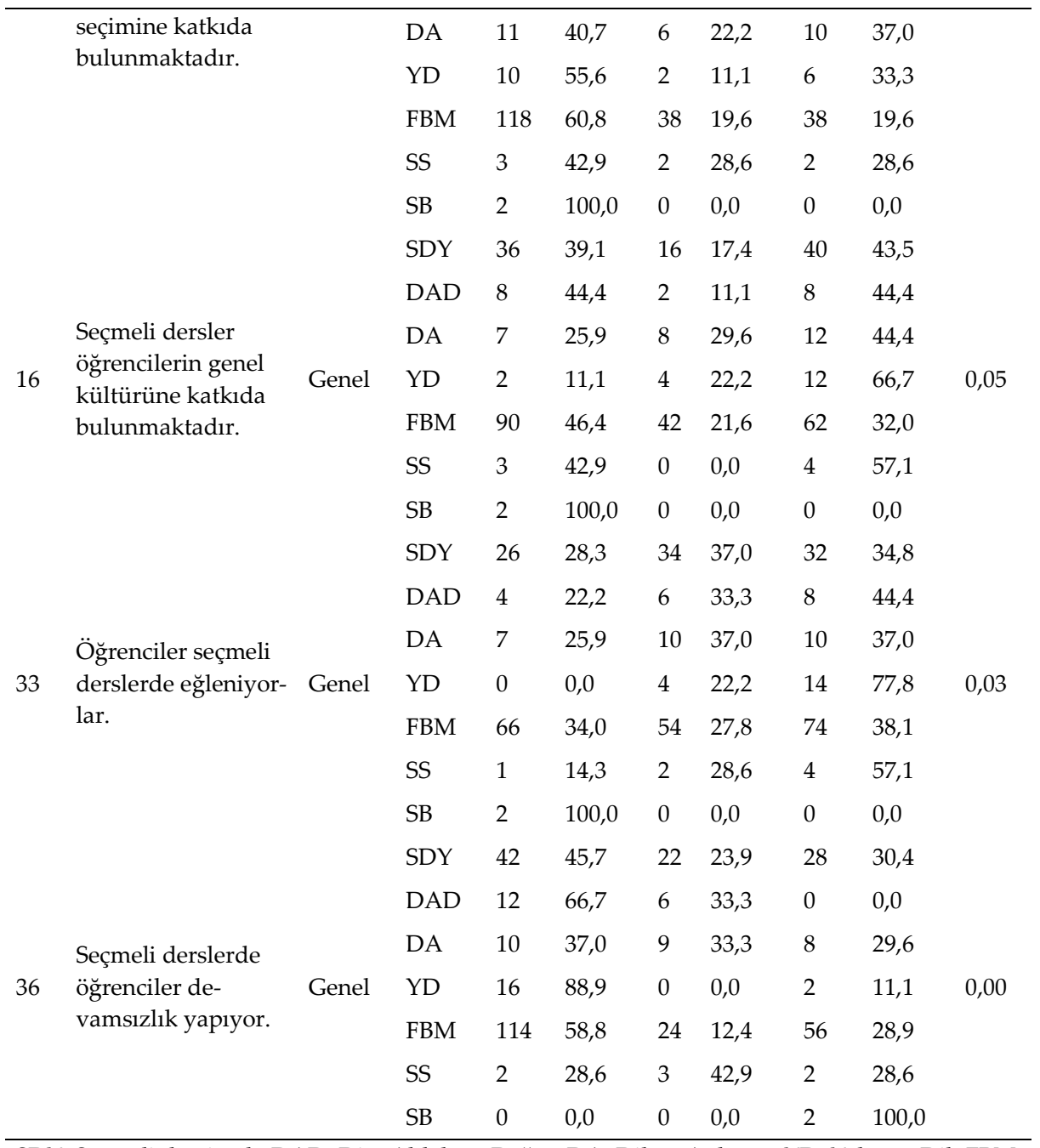

SDY: Seçmeli dersi yok; DAD: Din, Ahlak ve Değer; DA: Dil ve Anlatım; YD: Yabancı Dil; FBM: Fen Bilimleri ve Matematik; SS: Sanat ve Spor: SB: Sosyal Bilimler

Tablo 9-A incelendiğinde, sadece bir madde (Seçmeli dersler öğrencilerin bireysel farklılıklarını öne çıkarmaktadır.) hariç diğer tüm maddelerde öğretmenlerin seçmeli ders uygulaması hakkındaki görüşleri birbirinden farklılaşmaktadır. Herhangi bir seçmeli derse girmeyen öğretmenlerin yaklaşık üçte biri ya da daha fazlası ankette verilen maddelere katılmadıklarını belirtmişlerdir. Yabancı dil $(\% 88,9)$, Din, Ahlak ve Değer $(\% 66,7)$ ile Fen Bilimleri ve Matematik $(\% 48,5)$ alanlarındaki öğretmen- 
lerin önemli bir bölümünün seçmeli ders uygulamasını gerekli buldukları (Madde 3), buna karşılık Sosyal Bilimler (\%100), Sanat ve Spor $(\% 71,4)$ ve Dil ve Anlatım $(\% 40,7)$ alanlarında seçmeli dersleri yürüten öğretmenlerin seçmeli derslerin gereğine yeterince inanmadıkları ortaya çıkmıştır. Fen Bilimleri ve Matematik alanlarında seçmeli dersleri yürüten öğretmenlerin yarıya yakının da $(42,3)$ seçmeli ders uygulamasını gerekli görmedikleri görülmektedir. Seçmeli dersleri faydalı bulma durumu da üçüncü maddedeki oranlarla paralellik göstermiştir. "Girdiğim seçmeli ders branşıma uygundur. (Madde 5)" seçeneğine öğretmenlerin büyük bir çoğunluğu "katılıyorum" cevabını vermişlerdir. Ancak herhangi bir seçmeli derse girmeyen öğretmenler (\% $30,4)$ ile Din, Ahlak ve Değer $(\% 33,3)$ alanındaki seçmeli dersleri yürüten öğretmenler bu maddeyi "katılmıyorum" şeklinde işaretleyerek, gruplar arası farka neden olmuşlardır.

Araştırma kapsamındaki öğretmenler kendilerini oldukça yeterli bulmakta ve girdikleri seçmeli derslerle ilgili olarak hizmet içi seminerlere ihtiyaç duymamaktadırlar. Yine bu maddeye paralel olarak öğretmenlerin büyük bir bölümü seçmeli derslerin öğrencilerin bireysel farklılıklarını öne çıkarmadığını düşünmektedirler. Sadece Dil ve Anlatım $(\% 37,0)$ ile Sanat ve Spor alanlarındaki öğretmenlerin bir kısmı $(\% 28,6)$ farklı yönde görüş bildirmişlerdir. Öğretmenler seçmeli derslerin öğrencilerin yeteneklerini geliştirdiği konusunda birbirlerinden farklı düşünmektedirler. Aynı alandaki öğretmenlerin bir yarısı derslerin öğrencilerin yeteneklerini geliştirdiğini belirtirken, diğer yarısı ters yönde görüşlerini ortaya koymaktadır. Öğretmenlerin bir bölümü (\%2030) de bu konuda kararsız olduklarını belirtmişlerdir.

Seçmeli derslerin öğrencilerin meslek seçimine katkısı olup olmadığı konusunda da olumsuz düşünen öğretmen oranı olumlu düşünenlerden daha fazla ortaya çıkmıştır. Özellikle Din, Ahlak ve Değer $(\% 66,7)$, Fen Bilimleri ve Matematik $(\% 60,8)$ ve Yabancı Dil alanlarında seçmeli derse giren öğretmenler seçmeli derslerin öğrencilerin meslek seçimine etki etmediğini ifade etmişlerdir. Seçmeli derslerin öğrencilerin genel kültürüne katkıda bulunması konusunda da öğretmenler ikiye bölünmüş durumdadır. Sadece Yabancı Dil alanında seçmeli derslere giren öğretmenlerin üçte ikisi $(\% 66,7)$, derslerin öğrencilerin genel kültürüne katkıda bulunduğunu ifade etmişlerdir. Yine yabancı dil der- 
sine giren öğretmenler $(\% 77,8)$ Sanat ve Spor alanında derse giren öğretmenler $(\% 57,1)$, öğrencilerin derslerde eğlendiklerini belirtmekte, buna karşılık Sosyal Bilimler (\% 100), Fen Bilimleri ve Matematik (\%34,0) ile Dil ve Anlatım $(\% 25,9)$ alanlarında seçmeli derslere giren öğretmenler bu görüşe katılmadıklarını söylemişlerdir. Öğrencilerin derslere devamı konusunda öğretmenlerin çoğu olumlu görüş bildirmişler, sadece Sosyal Bilimler (\%100), Dil ve Anlatım $(\% 29,6)$, Fen Bilimleri ve Matematik $(\% 28,9)$ ile Sanat ve Spor $(\% 28,6)$ alanlarında derse giren öğretmenlerin bir bölümü öğrencilerin devamsızlık yaptıklarını belirtmişlerdir.

Aşağıdaki tabloda (Tablo 9-B) öğretmenlerin çalıştıkları okullardaki seçmeli ders uygulamalarına ilişkin görüşlerine ait Ki-Kare testi bulguları yer almaktadır.

Tablo 10-B. Öğretmenlerin çalıştıkları okullardaki seçmeli ders uygulamalarına ilişkin görü̈slerinin kıdemlerine göre farklılıkları

\begin{tabular}{|c|c|c|c|c|c|c|c|c|c|c|}
\hline $\begin{array}{l}\frac{0}{0} \\
\frac{\pi}{2} \\
\Sigma\end{array}$ & $\begin{array}{l}\text { ÖĞRETMEN } \\
\text { GÖRÜŞLERİ }\end{array}$ & $\begin{array}{l}\text { 节 } \\
\text { م. }\end{array}$ & $\frac{\widetilde{\pi}}{\gtrless}$ & $\mathrm{f}$ & 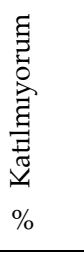 & $\mathrm{f}$ & 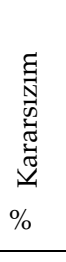 & $\mathrm{f}$ & 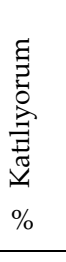 & \\
\hline \multirow{7}{*}{1} & \multirow{7}{*}{$\begin{array}{l}\text { Okulumuzda seçmeli } \\
\text { dersler etkili bir } \\
\text { şekilde uygulanmak- } \\
\text { tadır. }\end{array}$} & \multirow{7}{*}{ Uyg } & SDY & 46 & 50,0 & 32 & 34,8 & 14 & 15,2 & \multirow{7}{*}{0,00} \\
\hline & & & DAD & 0 & 0,0 & 4 & 22,2 & 14 & 77,8 & \\
\hline & & & DA & 7 & 25,9 & 14 & 51,9 & 6 & 22,2 & \\
\hline & & & YD & 8 & 44,4 & 2 & 11,1 & 8 & 44,4 & \\
\hline & & & FBM & 56 & 28,9 & 44 & 22,7 & 94 & 48,5 & \\
\hline & & & SS & 1 & 14,3 & 4 & 57,1 & 2 & 28,6 & \\
\hline & & & SB & 2 & 100,0 & 0 & 0,0 & 0 & 0,0 & \\
\hline \multirow{6}{*}{7} & \multirow{6}{*}{$\begin{array}{l}\text { Öğrencilere sunulan } \\
\text { seçmeli ders türü } \\
\text { yeterlidir. }\end{array}$} & \multirow{6}{*}{ Uyg } & SDY & 40 & 43,5 & 18 & 19,6 & 34 & 37,0 & \multirow{6}{*}{0,00} \\
\hline & & & DAD & 2 & 11,1 & 6 & 33,3 & 10 & 55,6 & \\
\hline & & & DA & 14 & 51,9 & 9 & 33,3 & 4 & 14,8 & \\
\hline & & & YD & 8 & 44,4 & 4 & 22,2 & 6 & 33,3 & \\
\hline & & & FBM & 46 & 23,7 & 48 & 24,7 & 100 & 51,5 & \\
\hline & & & SS & 0 & 0,0 & 3 & 42,9 & 4 & 57,1 & \\
\hline
\end{tabular}




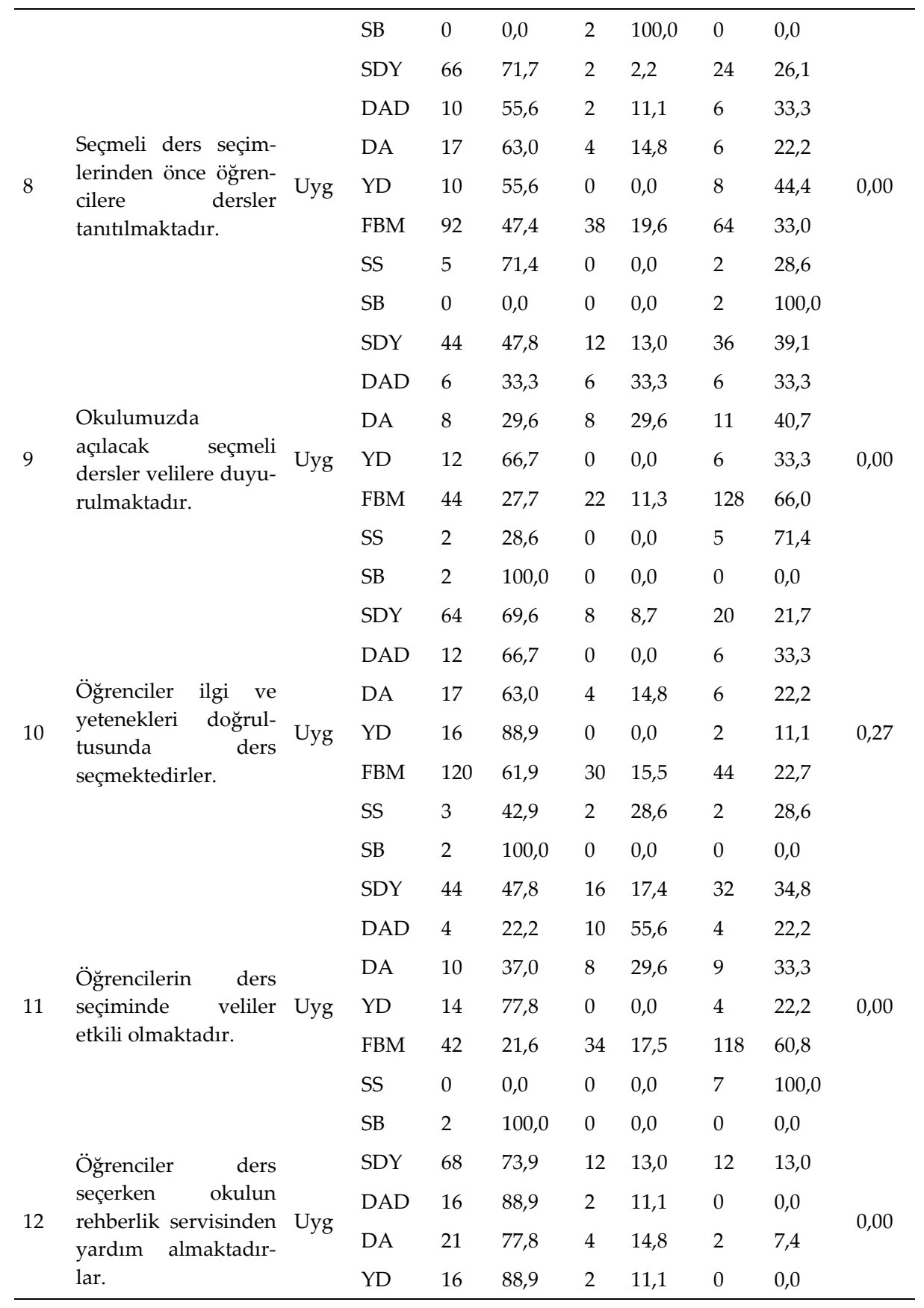




\begin{tabular}{llllllll}
\hline FBM & 126 & 64,9 & 44 & 22,7 & 24 & 12,4 \\
SS & 5 & 71,4 & 0 & 0,0 & 2 & 28,6 \\
SB & 0 & 0,0 & 0 & 0,0 & 2 & 100,0 \\
\hline
\end{tabular}

SDY: Seçmeli dersi yok; DAD: Din, Ahlak ve Değer; DA: Dil ve Anlatım; YD: Yabancı Dil; FBM: Fen Bilimleri ve Matematik; SS: Sanat ve Spor: SB: Sosyal Bilimler

Tablo 9-B incelendiğinde, öncelikli olarak öğretmenlerin sadece "Öğrenciler ilgi ve yetenekleri doğrultusunda ders seçmektedirler." konusunda benzer görüşleri savundukları dikkat çekmektedir. Öğretmenler hangi alandan olurlarsa olsunlar, seçmeli dersleri öğrencilerin kendi ilgi ve yetenekleri doğrultusunda seçmediklerini ifade etmişlerdir. Çalıştıkları okulda seçmeli derslerin etkili bir şekilde uygulandığını belirten öğretmenler en fazla Din, Ahlak ve Değer $(\% 77,8)$ alanında derse giren öğretmenler olmuştur. Bu alanı sırayla Fen Bilimleri ve Matematik (\%48,5) ile Yabancı Dil $(\% 44,4)$ alanlarında derse giren öğretmenler izlemiştir. Buna karşılık Dil ve Anlatım alanında derse giren öğretmenlerin yarısından fazlasının $(\% 51,9)$ bu konuda "kararsız" kaldığı görülmektedir.

Dil ve Anlatım $(\% 51,9)$ ile Yabanc Dil $(\% 44,4)$ alanlarında derse giren öğretmenler okullarındaki seçmeli ders türlerinin yetersiz olduğunu bildirmelerine karşıllk, Sanat ve Spor $(\% 57,1)$, Din, Ahlak ve Değer $(\% 55,6)$, Fen Bilimleri ve Matematik $(\% 51,5)$ alanlarında derse giren öğretmenler seçmeli ders türünün yeterli olduğunu ifade etmişlerdir. Altı alanın beşinde öğretmenlerin yarısından fazlası, ders seçimlerinden önce seçmeli derslerin öğrencilere tanıtılmadığını belirtmişler, sadece Sosyal Bilimler alanından araştırmaya katılan iki öğretmen farklı yönde görüş bildirmişlerdir. Açlacak seçmeli derslerin velilere duyurulması konusunda da öğretmenler ikiye bölünmüşlerdir. Örneğin Sanat ve Spor $(\% 71,4)$ ile Fen Bilimleri ve Matematik $(\% 66,0)$ alanlarındaki öğretmenler, seçmeli derslerin velilere daha önceden duyurulduğunu, ama buna karşlık Sosyal Bilimler (\%100) ve Yabancı Dil $(\% 66,7)$ alanlarındaki öğretmenler velilere daha önce hangi seçmeli derslerin açılacağının bildirilmediğini ifade etmişlerdir.

Öğrencilerin ders seçiminde velilerin etkili olduğunu bildiren öğretmenler daha çok Sanat ve Spor (\%100) ve Fen Bilimleri ve Matematik $(\% 60,8)$ alanlarında derse giren öğretmenler olmuştur. Sosyal Bilimler (\%100) ve Yabancı Dil $(\% 77,8)$ alanlarında seçmeli dersleri yürüten 
öğretmenler ise velilerin ders seçiminde etkili olmadığını belirtmişlerdir. Öğretmenlerin büyük bir çoğunluğu, öğrencilerin ders seçerken okulun rehberlik servisinden yardım almadıklarını belirtmiş, ancak Sosyal Bilimler (\%100), Sanat ve Spor $(\% 28,6)$ ve Fen Bilimleri ve Matematik $(\% 12,4)$ alanlarındaki öğretmenlerin bir kısmı öğrencilerin rehberlik biriminden bu anlamda yararlandıklarını ifade etmişlerdir.

Aşağıdaki tabloda öğrencilerin kendi yürüttükleri seçmeli derslerin öğretim sürecine ilişkin görüşlerine ait Ki-Kare testi bulguları yer almaktadir.

Tablo 11-C. Öğretmenlerin yürüttükleri seçmeli ders öğretim sürecine ilişkin görüşlerinin kıdemlerine göre farklılıklar

\begin{tabular}{|c|c|c|c|c|c|c|c|c|c|c|}
\hline $\begin{array}{l}\frac{0}{0} \\
\frac{\pi}{\pi}\end{array}$ & $\begin{array}{l}\text { ÖĞRETMEN } \\
\text { GÖRÜŞLERİ }\end{array}$ & 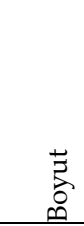 & $\frac{\Xi}{<}$ & $\mathrm{f}$ & 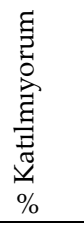 & $\mathrm{f}$ & 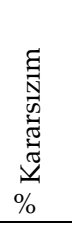 & $\mathrm{f}$ & 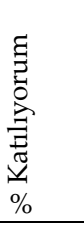 & \\
\hline \multirow{7}{*}{2} & \multirow{7}{*}{$\begin{array}{l}\text { Seçmeli dersler } \\
\text { amaçlarına uygun } \\
\text { olarak işlenmektedir. }\end{array}$} & \multirow{7}{*}{ Süreç } & SDY & 52 & 56,5 & 24 & 26,1 & 16 & 17,4 & \multirow{7}{*}{0,00} \\
\hline & & & DAD & 2 & 11,1 & 4 & 22,2 & 12 & 66,7 & \\
\hline & & & DA & 6 & 22,2 & 13 & 48,1 & 8 & 29,6 & \\
\hline & & & YD & 4 & 22,2 & 6 & 33,3 & 8 & 44,4 & \\
\hline & & & FBM & 68 & 35,1 & 62 & 32,0 & 64 & 33,0 & \\
\hline & & & SS & 0 & 0,0 & 3 & 42,9 & 4 & 57,1 & \\
\hline & & & SB & 2 & 100,0 & 0 & 0,0 & 0 & 0,0 & \\
\hline \multirow{7}{*}{17} & \multirow{7}{*}{$\begin{array}{l}\text { Seçmeli dersler zorunlu } \\
\text { derslere takviye dersi } \\
\text { gibi işlenmektedir. }\end{array}$} & \multirow{7}{*}{ Süreç } & SDY & 16 & 17,4 & 16 & 17,4 & 60 & 65,2 & \multirow{7}{*}{0,00} \\
\hline & & & DAD & 2 & 11,1 & 0 & 0,0 & 16 & 88,9 & \\
\hline & & & DA & 7 & 25,9 & 8 & 29,6 & 12 & 44,4 & \\
\hline & & & YD & 2 & 11,1 & 4 & 22,2 & 12 & 66,7 & \\
\hline & & & FBM & 14 & 7,2 & 18 & 9,3 & 162 & 83,5 & \\
\hline & & & SS & 1 & 14,3 & 2 & 28,6 & 4 & 57,1 & \\
\hline & & & SB & 0 & 0,0 & 0 & 0,0 & 2 & 100,0 & \\
\hline \multirow{7}{*}{18} & \multirow{7}{*}{$\begin{array}{l}\text { Girdiğim seçmeli dersin } \\
\text { öğretim programını } \\
\text { yeterli buluyorum. }\end{array}$} & \multirow{7}{*}{ Süreç } & SDY & 38 & 41,3 & 38 & 41,3 & 16 & 17,4 & \multirow{7}{*}{0,00} \\
\hline & & & DAD & 10 & 55,6 & 4 & 22,2 & 4 & 22,2 & \\
\hline & & & DA & 7 & 25,9 & 6 & 22,2 & 14 & 51,9 & \\
\hline & & & YD & 2 & 11,1 & 4 & 22,2 & 12 & 66,7 & \\
\hline & & & FBM & 84 & 43,3 & 54 & 27,8 & 56 & 28,9 & \\
\hline & & & SS & 7 & 100,0 & 0 & 0,0 & 0 & 0,0 & \\
\hline & & & SB & 0 & 0,0 & 0 & 0,0 & 2 & 100,0 & \\
\hline \multirow{5}{*}{19} & \multirow{5}{*}{$\begin{array}{l}\text { Seçmeli derslerin } \\
\text { amaçlarına derslerin } \\
\text { öğretim programında } \\
\text { yer verilmiştir. }\end{array}$} & \multirow{5}{*}{ Süreç } & SDY & 24 & 26,1 & 44 & 47,8 & 24 & 26,1 & \multirow{5}{*}{0,03} \\
\hline & & & DAD & 4 & 22,2 & 6 & 33,3 & 8 & 44,4 & \\
\hline & & & DA & 11 & 40,7 & 6 & 22,2 & 10 & 37,0 & \\
\hline & & & YD & 4 & 22,2 & 4 & 22,2 & 10 & 55,6 & \\
\hline & & & FBM & 58 & 29,9 & 60 & 30,9 & 76 & 39,2 & \\
\hline
\end{tabular}




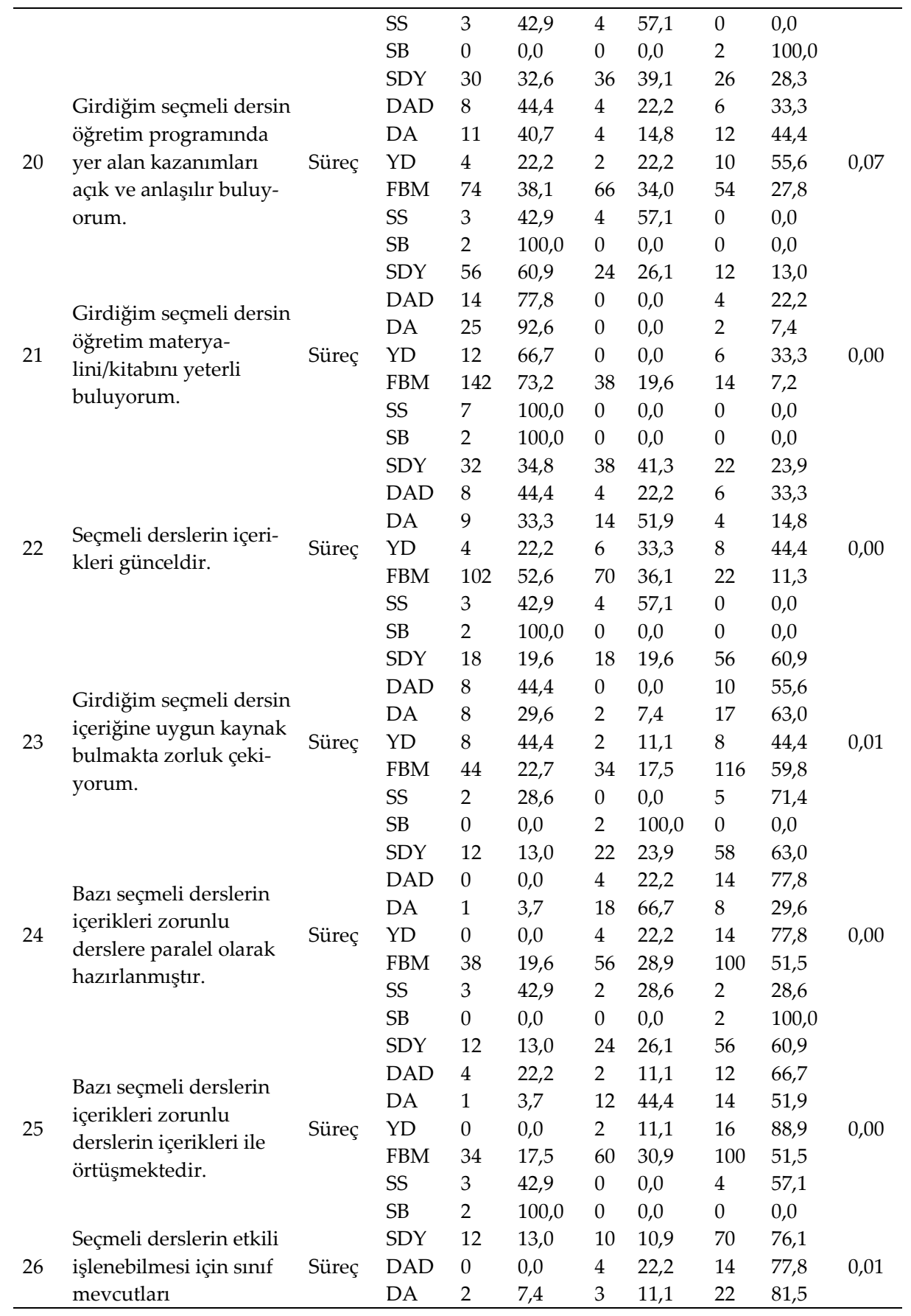




\begin{tabular}{|c|c|c|c|c|c|c|c|c|c|c|}
\hline & azaltılmalıdır. & & YD & 2 & 11,1 & 2 & 11,1 & 14 & 77,8 & \\
\hline & & & FBM & 16 & 8,2 & 20 & 10,3 & 158 & 81,4 & \\
\hline & & & SS & 0 & 0,0 & 1 & 14,3 & 6 & 85,7 & \\
\hline & & & SB & 2 & 100,0 & 0 & 0,0 & 0 & 0,0 & \\
\hline \multirow{7}{*}{27} & Seçmeli derslerin & & SDY & 58 & 63,0 & 10 & 10,9 & 24 & 26,1 & \\
\hline & işlenebilmesi için oku- & & DAD & 8 & 44,4 & 2 & 11,1 & 8 & 44,4 & \\
\hline & lun fiziksel olanakları & & DA & 13 & 48,1 & 10 & 37,0 & 4 & 14,8 & \\
\hline & (müzik odası, laboratu- & Süreç & YD & 12 & 66,7 & 0 & 0,0 & 6 & 33,3 & 0,00 \\
\hline & var, bilgisayar la- & & FBM & 108 & 55,7 & 44 & 22,7 & 42 & 21,6 & \\
\hline & boratuvarı, vb.) yeter- & & SS & 5 & 71,4 & 2 & 28,6 & 0 & 0,0 & \\
\hline & lidir. & & SB & 0 & 0,0 & 0 & 0,0 & 2 & 100,0 & \\
\hline \multirow{7}{*}{28} & \multirow{8}{*}{$\begin{array}{l}\text { Seçmeli derslerin } \\
\text { işlendiği mekânlar } \\
\text { etkili bir şekilde } \\
\text { kullanılmaktadır. }\end{array}$} & \multirow{7}{*}{ Süreç } & SDY & 48 & 52,2 & 22 & 23,9 & 22 & 23,9 & \\
\hline & & & DAD & 4 & 22,2 & 6 & 33,3 & 8 & 44,4 & \\
\hline & & & $\mathrm{DA}$ & 11 & 40,7 & 12 & 44,4 & 4 & 14,8 & \\
\hline & & & YD & 10 & 55,6 & 0 & 0,0 & 8 & 44,4 & 0,00 \\
\hline & & & FBM & 96 & 49,5 & 70 & 36,1 & 28 & 14,4 & \\
\hline & & & SS & 5 & 71,4 & 0 & 0,0 & 2 & 28,6 & \\
\hline & & & SB & 2 & 100,0 & 0 & 0,0 & 0 & 0,0 & \\
\hline \multirow{7}{*}{29} & & \multirow{7}{*}{ Süreç } & SDY & 66 & 71,7 & 10 & 10,9 & 16 & 17,4 & \\
\hline & \multirow{6}{*}{$\begin{array}{l}\text { Seçmeli dersler için } \\
\text { gerekli araç gereç oku- } \\
\text { lumuzda bulunmak- } \\
\text { tadır. }\end{array}$} & & DAD & 4 & 22,2 & 8 & 44,4 & 6 & 33,3 & \\
\hline & & & $\mathrm{DA}$ & 13 & 48,1 & 14 & 51,9 & 0 & 0,0 & \\
\hline & & & YD & 10 & 556,0 & 2 & 11,1 & 6 & 33,3 & 0,00 \\
\hline & & & FBM & 104 & 53,6 & 58 & 29,9 & 32 & 16,5 & \\
\hline & & & SS & 5 & 71,4 & 2 & 28,6 & 0 & 0,0 & \\
\hline & & & SB & 0 & 0,0 & 0 & 0,0 & 2 & 100,0 & \\
\hline \multirow{7}{*}{30} & \multirow{7}{*}{$\begin{array}{l}\text { Seçmeli ders öncesi } \\
\text { hazırlıklarım uzun } \\
\text { sürüyor. }\end{array}$} & \multirow{7}{*}{ Süreç } & SDY & 32 & 34,8 & 32 & 34,8 & 28 & 30,4 & \\
\hline & & & DAD & 8 & 44,4 & 4 & 22,2 & 6 & 33,3 & \\
\hline & & & DA & 15 & 55,6 & 8 & 29,6 & 4 & 14,8 & \\
\hline & & & YD & 10 & 55,6 & 2 & 11,1 & 6 & 33,3 & 0,02 \\
\hline & & & FBM & 66 & 34,0 & 66 & 34,0 & 62 & 32,0 & \\
\hline & & & SS & 1 & 14,3 & 0 & 0,0 & 6 & 85,7 & \\
\hline & & & SB & 2 & 100,0 & 0 & 0,0 & 0 & 0,0 & \\
\hline \multirow{7}{*}{31} & \multirow{7}{*}{$\begin{array}{l}\text { Seçmeli dersleri işlerk- } \\
\text { en farklı yöntem ve } \\
\text { tekniklerden fayda- } \\
\text { lanıyorum. }\end{array}$} & \multirow{7}{*}{ Süreç } & SDY & 24 & 26,1 & 34 & 37,0 & 34 & 37,0 & \\
\hline & & & DAD & 2 & 11,1 & 4 & 22,2 & 12 & 66,7 & \\
\hline & & & DA & 7 & 25,9 & 10 & 37,0 & 10 & 37,0 & \\
\hline & & & YD & 0 & 0,0 & 0 & 0,0 & 18 & 100,0 & 0,00 \\
\hline & & & FBM & 50 & 25,8 & 68 & 35,1 & 76 & 39,2 & \\
\hline & & & SS & 1 & 14,3 & 0 & 0,0 & 6 & 85,7 & \\
\hline & & & SB & 0 & 0,0 & 2 & 100,0 & 0 & 0,0 & \\
\hline \multirow{7}{*}{32} & \multirow{7}{*}{$\begin{array}{l}\text { Seçmeli dersleri işler- } \\
\text { ken görsel/işitsel ma- } \\
\text { teryal kullaniyorum. }\end{array}$} & \multirow{7}{*}{ Süreç } & SDY & 18 & 19,6 & 36 & 39,1 & 38 & 41,3 & \\
\hline & & & DAD & 4 & 22,2 & 2 & 11,1 & 12 & 66,7 & \\
\hline & & & DA & 5 & 18,5 & 12 & 44,4 & 10 & 37,0 & \\
\hline & & & YD & 0 & 0,0 & 0 & 0,0 & 18 & 100,0 & 0,00 \\
\hline & & & FBM & 42 & 21,6 & 60 & 30,9 & 92 & 47,4 & \\
\hline & & & SS & 1 & 14,3 & 0 & 0,0 & 6 & 85,7 & \\
\hline & & & SB & 0 & 0,0 & 2 & 100,0 & 0 & 0,0 & \\
\hline 34 & Seçmeli derslerde & Süreç & SDY & 42 & 45,7 & 12 & 13,0 & 38 & 41,3 & 0,04 \\
\hline
\end{tabular}




\begin{tabular}{|c|c|c|c|c|c|c|c|c|c|c|}
\hline & \multirow{7}{*}{\multicolumn{2}{|c|}{$\begin{array}{l}\text { öğrencilerin başarısı not } \\
\text { ile değerlendirilmelidir. }\end{array}$}} & DAD & 6 & 33,3 & 0 & 0,0 & 12 & 66,7 & \\
\hline & & & DA & 17 & 63,0 & 4 & 14,8 & 6 & 22,2 & \\
\hline & & & YD & 6 & 33,3 & 2 & 11,1 & 10 & 55,6 & \\
\hline & & & FBM & 84 & 43,3 & 42 & 21,6 & 68 & 35,1 & \\
\hline & & & SS & 3 & 42,9 & 0 & 0,0 & 4 & 57,1 & \\
\hline & & & SB & 2 & 100,0 & 0 & 0,0 & 0 & 0,0 & \\
\hline & & & SDY & 34 & 37,0 & 10 & 10,9 & 48 & 52,2 & \\
\hline \multirow{6}{*}{35} & \multirow{6}{*}{$\begin{array}{l}\text { Seçmeli derslerin not ile } \\
\text { değerlendirilmeye } \\
\text { başlaması ile öğrenciler } \\
\text { bu dersleri daha } \\
\text { ciddiye aldılar. }\end{array}$} & \multirow{6}{*}{ Süreç } & DAD & 0 & 0,0 & 0 & 0,0 & 18 & 100,0 & \multirow{6}{*}{0,00} \\
\hline & & & DA & 11 & 40,7 & 6 & 22,2 & 10 & 37,0 & \\
\hline & & & YD & 0 & 0,0 & 2 & 11,1 & 16 & 88,9 & \\
\hline & & & FBM & 62 & 32,0 & 24 & 12,4 & 108 & 55,7 & \\
\hline & & & SS & 1 & 14,3 & 2 & 28,6 & 4 & 57,1 & \\
\hline & & & SB & 2 & 100,0 & 0 & 0,0 & 0 & 0,0 & \\
\hline \multirow{7}{*}{37} & \multirow{7}{*}{$\begin{array}{l}\text { Girdiğim seçmeli derste } \\
\text { farklı ölçme değer- } \\
\text { lendirme yöntemleri } \\
\text { kullanıyorum. }\end{array}$} & \multirow{7}{*}{ Süreç } & SDY & 28 & 30,4 & 32 & 34,8 & 32 & 34,8 & \multirow{7}{*}{0,06} \\
\hline & & & DAD & 6 & 33,3 & 4 & 22,2 & 8 & 44,4 & \\
\hline & & & DA & 7 & 25,9 & 8 & 29,6 & 12 & 44,4 & \\
\hline & & & YD & 6 & 33,3 & 2 & 11,1 & 10 & 55,6 & \\
\hline & & & FBM & 66 & 34,0 & 60 & 30,9 & 68 & 35,1 & \\
\hline & & & SS & 1 & 14,3 & 6 & 85,7 & 0 & 0,0 & \\
\hline & & & SB & 2 & 100,0 & 0 & 0,0 & 0 & 0,0 & \\
\hline
\end{tabular}

SDY: Seçmeli dersi yok; DAD: Din, Ahlak ve Değer; DA: Dil ve Anlatım; YD: Yabancı Dil; FBM: Fen Bilimleri ve Matematik; SS: Sanat ve Spor: SB: Sosyal Bilimler

Tablo 9-C'de programın hedeflerine ilişkin maddeler (Madde 19 ve 20) incelendiğinde; seçmeli derslerin amaçlarına programda yer verildiği ve programda kullanılan dilin açık ve anlaşılır olduğu konusunda öğretmenler alanlarına göre farklı görüşler bildirmişlerdir. Dersin amaçlarının programda yer aldığı konusunda Sosyal Bilimler (\%100), Yabancı Dil $(\% 55,6)$ ile Din, Ahlak ve Değer (\%44,4) alanındaki öğretmenlerin önemli bir kısmı olumlu görüş bildirmelerine karşılık, özellikle Sağlık ve Spor $(\% 42,9)$, Dil ve Anlatım $(\% 40,7)$ ile Fen Bilimleri ve Matematik $(\% 29,9)$ alanındaki öğretmenler yer almadığını ifade etmişlerdir.

Öğretmenlerin okullarında yürüttükleri seçmeli derslerin içerikleri konusundaki görüşlerine ilişkin maddeler (Madde 22, 23, 24, 25) incelendiğinde; seçmeli derslerin içeriklerinin güncel olduğunu düşünen öğretmenlerin en fazla Yabancı Dil $(\% 44,4)$ alanında ders veren öğretmenler olduğu görülmektedir. Diğer alanlardaki öğretmenler genellikle derslerin içeriklerinin güncel olmadığı görüşündeler. Bu bağlamda öğretmenlerin görüşleri arasında bir uyum ortaya çıkmamıştır. Söz konusu derslerin içeriğine uygun kaynak bulmak konusunda da öğretmenler farklı görüşler beyan etmişlerdir. Sağlık ve Spor (\%71,4), Dil ve Anlatım $(\% 63,0)$, Fen Bilimleri ve Matematik $(\% 59,8)$ ile Din, Ahlak ve 
Değer $(\% 55,6)$ alanlarında derse giren öğretmenler kaynak konusunda sıkıntı çekiklerini, buna karşılık tüm alanlardaki öğretmenlerin önemli bir kısmı kaynak konusunda sıkıntı yaşamadıklarını ifade etmişlerdir. Öğretmenlerin büyük bir bölümü "Bazı seçmeli derslerin içerikleri zorunlu derslere paralel olarak hazırlanmıştır" seçeneğine "katılıyorum" ş̧eklinde görüş bildirirken, özellikle Sağlık ve Spor $(\% 42,9)$ alanındaki öğretmenler içeriklerin benzemediğini ifade etmiştir. 25. maddede belirtilen, içeriklerin zorunlu derslerle örtüştügüune ilişkin görüşte de benzer sonuçlar elde edilmiştir.

Seçmeli derslerin işleniş (öğretme-öğrenme süreci) boyutuna ilişkin öğretmen görüşleri incelendiğinde; öğretmenlerin seçmeli dersleri sanki zorunlu derslere takviye gibi algıladıkları söylenebilir. Özellikle Din, Ahlak ve Değer, Fen Bilimleri ve Matematik ile Yabancı Dil alanlarındaki derslere giren öğretmenlerin yarısından fazlası derslerin amaçlarına uygun ve zorunlu derslere takviye dersi gibi işlendiğini ifade etmişlerdir. Öğretmenlerin çoğu girdikleri seçmeli derslerin materyalleri ve/veya ders kitapları konusunda sıkıntı yaşadıklarını ifade etmişler, Yabancı Dil $(\% 33,3)$ ve Din, Ahlak ve Değer $(\% 22,2)$ alanlarındaki öğretmenler materyalleri yeterli bulmuşlardır. Seçmeli derslere ilişkin kaynak bulma ve okullardaki araç gereç konusunda öğretmenlerin aynı görüşü paylaşmadıkları görülmektedir. Bu derslerin daha etkili işlenebilmesi için sınıf mevcutlarının azaltılması ve okulun fiziksel olanaklarının artırılması konusunda benzer görüşler ortaya koymuşlardır. Ancak özellikle Sosyal Bilimler (\%100), Din, Ahlak ve Değer (\%44,4) ile Yabancı Dil $(\% 33,3)$ alanlarındaki öğretmenler fiziksel olanakların yeterli olduğunu vurgulamışlardır. Öğretmenler ayrıca ders mekânlarının etkili kullanılmadığını ifade etmişlerdir. Ö̆ğretmenlerin büyük bir çoğunluğu seçmeli derslerde farklı yöntem kullandıklarını, görsel ve işitsel materyalleri kullandıklarını belirtmiş, özellikle Fen Bilimleri ve Matematik $(\% 25,8)$ ile Dil ve Anlatım $(\% 25,9)$ alanlarındaki öğretmenlerin dörtte biri bu derslerde farklı yöntem ve teknik kullanmadıklarını ifade etmişlerdir.

Seçmeli derslerde öğrenci başarısının değerlendirilmesinde not kullanılması konusunda da öğretmenler farklı görüşler bildirmişlerdir. Din, Ahlak ve Değer $(\% 66,7)$, Sağlık ve Spor $(\% 57,1)$ ile Yabancı Dil $(\% 55,6)$ alanlarındaki öğretmenler nottan yana görüş bildirirken, özellikle Dil ve Anlatım $(\% 63,0)$ alanı olmak üzere diğer alanlardaki öğret- 
menlerin önemli bir kısmı bu derslerde öğrenci performansının not ile değerlendirilmemesi gerektiği görüşünü belirtmişlerdir. Ancak Sosyal Bilimler (\%100), Dil ve Anlatım (\%40,7) ile Fen Bilimleri ve Matematik $(\% 32,0)$ alanlarındaki öğretmenler, öğrencilerin seçmeli derslerin notla değerlendirilmeye başlamasından sonra dersleri daha ciddiye almadıklarını, yani notun çok da önemli bir etkisinin olmadığını ifade etmişlerdir. Seçmeli derslerde farklı ölçme araç ve yöntemleri kullanma konusunda görüşler alan farkı olmaksızın üçe ayrılmıştır; bazı öğretmenler bu görüsse katıldıklarını, bazıları katılmadığını ve bir kısım öğretmen de kararsız olduklarını belirtmişlerdir.

\section{Sonuç Tartışma ve Öneriler}

$\mathrm{Bu}$ bölümde araştırmanın alt problemleri doğrultusunda bulgulardan elde edilen sonuçlara yer verilmektedir.

\section{Seçmeli Derslerin Alan ve Derslere Göre Dağılımı}

Okullarda uygulanan seçmeli derslerin tercihine ya da açılan derslere bakıldığında, derslerin daha çok zorunlu derslere takviye gibi düşünülen derslerden açıldığı ortaya çıkmıştır. Ayrıca öğrenciler ders seçimlerini, önlerine çıkacak sınavları dikkate alarak yapmışlardır. Bu bağlamda Matematik Uygulamaları, Kur'an-1 Kerim, Okuma Becerileri dersleri en fazla açılan dersler arasına girmiştir. Örs ve diğerlerinin (2015) yaptı̆̆ "5. Sınıf Seçmeli Ders Tercihlerinin Sıralama Yargıları Kanunuyla Ölçeklendirilmesi" adlı çalışmada beşinci sınıf öğrencilerinin daha çok Spor ve Fiziki Etkinlikler, Yabancı Dil ve Zekâ Oyunları gibi dersleri tercih ettikleri ortaya çıkmıştır. Aynı çalışmada erkek öğrencilerde Spor ve Fiziki Etkinlikler birinci sırada iken, kız öğrencilerde Yabancı Dil ilk sırayı almıştır (Örs, Özdil ve Kınay, 2013). Karagözoğlu (2015) 'nun seçmeli derslerle ilgili çalışmasında 5. Sınıf öğrencilerinin en fazla Matematik, Kur'an-1 Kerim ve Yabanc1 Dil derslerini tercih ettiklerini ortaya koymuştur. Öğrenciler Karagözoğlu (2015)'nunçalışmasında, bu dersleri tercih nedenlerinin öncelikle ilgilerini çektiğini, böylece yeteneklerini geliştirebileceklerini, gelecekte meslek seçiminde bu derslerin katkısı olacağını ve bu derslerin kolay olmasından dolayı not ortalamasını 
yükselteceğini belirtmişlerdir. Karagözoğlu'nun çalışmasından elde edilen sonuçlar yapılan bu çalışmayla da paralellik göstermektedir. Türkiye'nin uluslararası PISA sınavlarında özellikle Matematik dersindeki başarı durumu göz önünde bulundurulduğunda, seçmeli derslerin başında Matematik dersinin gelmesi, gelişen dünyaya ayak uydurabilme anlamında sevindirici bir gelişme olarak kabul edilebilir. Seçmeli ders sıralamasında ikinci tercihin Kur'an-1 Kerim olması, veli, öğrenci ya da okulun, öğrencilerin yazın camilerde yapılan kurslar aracilığıyla öğrendikleri dini bilgileri daha düzenli ve programlı olarak okulda alması gerektiğini düşünmesinden kaynaklanabilir. Yaşayan Diller ve Lehçeler, İletişim ve Sunum Becerileri ve Medya Okuryazarlı̆̆ı gibi derslerin en az tercih edilmesinin nedeni, ders seçiminde etkili olan öğrenci, veli ya da okulun öncelikle akademik kaygılarından kaynaklandığı sonucunu doğurmaktadır. Ayrıca Matematik, Yabancı dil ve Türkçe gibi zorunlu dersleri desteklemesi, zorunlu derslerin notlarına etkisi ve böylece akademik başarıyı yükselteceği düşüncesi de öğrencilerin bu dersleri daha çok tercih etmelerinin nedeni olarak görülmektedir.

\section{Seçmeli Ders Uygulaması ve Açılma Koşulları}

Öğrencilerin ilgi, yetenek ve isteklerine göre açlarak, onların söz konusu becerilerini geliştirmek amacıyla öğretim programlarına konulan seçmeli derslerin türünü mevcut şartlarda çoğunlukla okul idaresinin belirlediği ortaya çıkmıştır. Kısmen öğretmen ve velilerin de etkili olduğu seçmeli ders tercihlerinde en az etkinin öğrenciler olduğu görülmektedir. Öğretmenlere göre derslerin açılmasında öğrencilerin isteklerinin en önemli etken olduğu ifade edilmiştir ancak bunun yanı sıra okulun fiziksel olanakları ve öğrencinin seçtiği derse girecek öğretmenin olup olmaması ve ders yükü de önemli ölçütler arasında sayılmıştır. Kutlu ve arkadaşlarının yaptığı çalışmada Mühendislik Fakültesi öğrencilerinin ders seçiminde sırayla ilgi alanı, dersin işleniş tarzı, ders programı ve derse giren öğretim alanı gibi ölçütleri ön planda tuttukları ortaya çıkmıştır (Kutlu, Abalı ve Eren, 2012). Yapılan bu çalışmaya paralel olarak Sağır'ın Eğitim ve okul sistemindeki son dönem politika değişimlerine ilişkin okul yöneticilerinin görüşlerinin incelediği çalışmasında, okul yöneticileri ders seçiminin, her alanda öğretmen bulma sıkıntısın- 
dan dolayı öğrenci ve veli tercihinden çok kurumun yönlendirilmesi yoluyla yapıldığını ifade etmişlerdir (Sağır, 2015).

\section{Seçmeli Dersler Hakkındaki Görüşler ve Okullarda Uygulanışı}

Araştırma kapsamındaki okullarda açılan seçmeli derslere büyük oranda alanın öğretmenlerinin girdiği ortaya çıkmıştır. Ancak öğretmenlerin alanı kapsamında olmayan seçmeli derslere girdiği de görülmektedir. Öğretmenlerin çoğuna göre seçmeli dersler yararlı ve gereklidir. Ancak seçmeli derslerin öğrencilerin bireysel farklılıkları ortaya çıkaracak nitelikte olmadığ1 ve meslek seçimine önemli bir etkisinin olmadığ1 anlaşılmaktadır. Demir ve Ok (1996)'un üniversite öğretim üyeleri ve öğrencileri ile yaptığı çalışmada, öğrenciler seçmeli derslerin öğrencilerin izlediği programla ve meslekleri ile ilgili olması gerektiğini belirtirken, öğretim üyeleri seçmeli derslerin daha kapsamlı olması gerektiğini bildirmişlerdir (Demir ve Ok, 1996). Öğretmenlerin dörtte üçü girdikleri seçmeli derslerle ilgili herhangi bir hizmetiçi eğitime gereksinim duymamaktadir.

Araştırmada seçmeli derslerle ilgili duyuruların zamanında ilgili kişilere (veli, öğrenci, öğretmen) yapıldığı ortaya çıkmıştır. Ancak seçmeli ders türünün yeterli olduğu ve ders seçiminde velilerin etkili olduğu görüşleri konusunda öğretmenler farklı düşünmektedir. Öğretmenlere göre öğrenciler kendi ilgi ve yetenekleri doğrultusunda değil karşılaşacakları sınavları dikkate alarak ders seçmektedirler. Karagözoğlu (2015)'nun yaptığı çalışmanın sonuçları her ne kadar öğrencilerden bilgi alınmışsa da büyük oranda bu çalışmayla benzerlik göstermektedir (Karagözoğlu, 2015). Seçmeli derslerin duyurulması ve okullardaki uygulanma şekli konusunda tarafların kafa karışıklıkları ve organizasyonların daha etkili yapılabilmesi, dönemin başında "okul rehberlik birimi ya da sınıf öğretmenlerinin veya her ikisinin de katılımıyla yapılacak toplantılara" bağlıdır (Ülgen, 1992). Seçmeli derslerin amaçlarının anlaşılırlığı, derslerde öğretim programlarının amaçlarına yer verilip verilmediği ve ekili bir şekilde işlendiği konusunda öğretmenler genellikle olumsuz görüş bildirmişlerdir. Uysal'ın (2015) yapı̆̆ı çalışma sonuçları ile de paralellik gösteren bu sonuca göre daha sürecin başında öğretmenlerin önünde önemli bir sorun bulunmaktadır. Çünkü 
programların hedef boyutuna ilişkin karşılaşılabilecek bir sorun diğer tüm boyutları etkilemektedir.

\section{Seçmeli Derslerin Öğretim Sürecine İlişkin Değerlendirme}

Öğretmenlerin büyük bir bölümü seçmeli derslerde sınıfların çok kalabalık olmasında şikâyetçi olmuştur. Yine süreçle ilgili olarak, öğretmenlerin girdikleri seçmeli derslerle ilgili kaynak, ders materyali ve araç gereç bulma, seçmeli derslerin notla değerlendirilmesi, sadece bu yüzden öğrencilerin dersi daha ciddiye almaları noktasında sorun yaşadıkları ortaya çıkmıştır. Öğretmenler seçmeli ders içeriklerinin zorunlu dersleri destekler nitelikte hazırlandığını ifade etmişlerdir. Öğretmenlerin çoğu seçmeli derslerin notla değerlendirilmesinin seçmeli ders ruhuna aykırı olduğu görüşünü belirtmişlerdir. Öğretmenler seçmeli derslerin işlenme sürecinde okulun olanakların yeterli olmadığını, ders mekânlarının yeterince verimli kullanılamadığını ifade etmişlerdir. Bu sonuç Uysal'ın yapı̆̆ı araştırma sonuçları ile paralellik göstermektedir (Uysal, 2015).

\section{Seçmeli Dersler Hakkındaki Genel, Uygulama ve Süreç Boyutuna İlişkin Öğretmen Görüşlerinin Cinsiyet Değişkenine Göre Farklılaş- masi}

Seçmeli dersler hakkındaki genel görüşler incelendiğinde, sadece 4 maddede erkek öğretmenlerin görüşleri ile kadın öğretmenlerin görüşleri arasında fark ortaya çıkmış, erkek öğretmenlerin seçmeli dersleri daha yararlı bulduğu, kadın öğretmenlerin branşına uygun seçmeli derse girme oranı ise erkek öğretmenlerden yüksek olduğu tespit edilmiştir. Seçmeli ders uygulaması ile ilgili kadın öğretmenlerin erkeklere oranla daha iyimser olmadığı ortaya çıkmıştır.

Seçmeli derslerin okullardaki uygulanmasına ilişkin olarak erkek öğretmenlerin çoğunluğu seçmeli ders türlerinin yeterli olduğu görüşünde birleşirken, bu oran kadın öğretmenlerde daha az bulunmuştur. Seçmeli derslerin velilere duyurulması konusunda ise, kadın öğretmenler genellikle duyurulduğunu, erkek öğretmenler ise duyurulmadığını belirtmişlerdir. 
Seçmeli dersleri öğretmenlerin sınıflarında öğretme sürecine ilişkin 20 soru yöneltilmiş, erkek ve kadın öğretmenlerin bu konudaki görüşleri 5 maddede farklılık göstermiştir. Öğretmenler bu sürecin bir parçası olan okulun fiziksel olanakları konusunda olumsuz görüş bildirmişler; müzik odası, laboratuvar, bilgisayar laboratuvarı, vb. fiziksel koşulların ve ders araç gereçlerinin yetersizliğini kadın öğretmenler erkek öğretmenlerden daha fazla hissetmektedir. Erkek öğretmenlerin yarıya yakını seçmeli dersleri işlerken farklı yöntemlerden yararlandığını belirtmiş, kadın öğretmenler ise çok az bir bölümü aynı görüşü paylaşmıştır. Öğrenci performansının not ile değerlendirilmesi gerektiği görüşüne erkek öğretmenler kadın öğretmenlere göre daha olumlu bakmaktadırlar.

\section{Seçmeli Dersler Hakkındaki Genel, Uygulama ve Süreç Boyutuna İlişkin Öğretmen Görüşlerinin Alan Değişkenine Göre Farklılaşması}

Öğretmenlerin alanlarına göre seçmeli dersler hakkındaki genel görüşler incelendiğinde, özellikle Yabancı Dil, Din, Ahlak ve Değer, Fen Bilimleri ve Matematik alanlarındaki öğretmenler diğer alanlardaki öğretmenlere göre seçmeli derslerin yararlarına ve gerekliliğine daha fazla inanmaktadırlar. Din, Ahlak ve Değer alanındaki dersler dışında öğretmenlerin çoğu özellikle Fen Bilimleri ve Matematik ile Dil ve Anlatım alanı öğretmenlerinin kendi branşlarına uygun derslere girdiği anlaşılmaktadır. Öğretmenler çoğunlukla seçmeli derslerin meslek seçimine, bireysel özelliklerin gelişimine beklenilen düzeyde katkısı olmadığını vurgulamıştır. Aynı alanlardaki öğretmenler bu konuda diğer öğretmenlere göre daha olumsuz bakmaktadırlar. Öğretmenlerin alanlarına göre görüşleri arasında farklılık görülse de, öğrencilerin seçmeli dersleri özellikle notla değerlendirilmeye başladıktan sonra zorunlu ders gibi algiladıkları, önemli gördükleri derslerde ciddi, daha çok sosyal etkinlik içerikli derslerde ise eğlenmeye çalıştıkları anlaşılmaktadır. Özellikle yukarıda belirtilen Yabancı Dil, Din, Ahlak ve Değer, Fen Bilimleri ve Matematik alanlarındaki öğretmenler okullarında seçmeli derslerin etkili bir şekilde işlendiğini dile getirirken Dil ve Anlatım alanında derse giren öğretmenlerin yarısından fazlasının (\% 51,9) bu konuda "kararsız" kaldığ görülmektedir. Derslerin velilere duyurulması, ders seçiminde etkili olan kişiler konusunda öğretmenler birbirinden farklı düşünmektedirler. 
Öğretim programın boyutlarına (amaç, içerik, eğitim süreci ve değerlendirme) ilişkin değerlendirmede, programın amaçlarına Sosyal Bilimler, Yabancı Dil ile Din, Ahlak ve Değer alanlarındaki öğretmenler seçmeli derslerde yer verildiğini ifade ederken, Sağllk ve Spor, Dil ve Anlatım ile Fen Bilimleri ve Matematik alanlarındaki öğretmenler yer verilmediği görüşündedirler. Seçmeli ders içeriklerinin güncel olduğu konusunda sadece Yabancı Dil öğretmenlerinin yarıya yakınının iyimser düşünmesinin dişında öğretmenlerin çoğu bu konuda olumsuz görüş bildirmişlerdir. Kaynak bulma konusunda da, Sağlık ve Spor, Dil ve Anlatım, Fen Bilimleri ve Matematik ile Din, Ahlak ve Değer alanlarında derse giren öğretmenler sıkıntı çekiklerini, buna karşılık tüm alanlardaki öğretmenlerin önemli bir kısmı kaynak konusunda sıkıntı yaşamadıklarını ifade etmişlerdir.

Öğrencilerin özellikle geleceklerini şekillendireceğini düşündükleri derslerle ilgili olan dersleri bir takviye gibi gördükleri için bu derslerin daha ciddi geçtiğini, diğer derslerde devamsızlıkların yaşandığı ortaya çıkmıştır. Yabancı Dil ile Din, Ahlak ve Değer alanındaki öğretmenler dışında kalan alanlardaki öğretmenler ders araçları, materyal, kaynak vb. konuda sıkıntı yaşadıklarını, öğretmenlerin çoğu ise seçmeli derslerde sınıf mevcutlarının azaltılması gereğini vurgulamışlardır. Din, Ahlak ve Değer, Sağlık ve Spor ile Yabancı Dil alanlarındaki öğretmenler dışında kalanlar öğrenci performanslarını değerlendirmede not kullanılmaması gerektiği konusunda görüş birliğine varmışlardır.

Yukarıdaki sonuçlar dikkate alınarak aşağıdaki öneriler yapılabilir:

1. Seçmeli derslerin amaçları, içeriği, uygulanma şekli ve tercih ölçütleri konusunda öğrenci ve velilere dönemin başında ayrıntılı bilgi verilmelidir. Bu uygulamada Okul Rehberlik Servisi bir daha etkin hale getirilmelidir.

2. Öğrencilerin ilgi, istek ve yeteneklerini ortaya çıkarabilmek amaciyla dönem başında söz konusu becerileri ortaya koyabilecek ölçekler geliştirerek uygulamak gerekmektedir.

3. Seçmeli ders uygulamasının başarılı olabilmesi için öğrencilerin ilgi, istek ve yetenekleri doğrultusunda seçmeli dersler oluşturulmasına okul yöneticileri dikkat etmelidir. 
4. Seçmeli ders amaçlarının içerisinde mesleki gelişime önem veren öğrencilerin üst sınıflarda da aynı dersleri seçmeleri için sürekliliği sağlayabilecek koordinasyonlar yapılmalıdır.

5. Öğrencilerin seçmeli ders tercihlerinde belirli derslerde yığılmalar olması durumunda yakın çevredeki öğretmen ve okullardan yararlanilmalıdir.

6. Seçmeli derslerdeki performansların değerlendirilmesinde not sadece bir üst kurdaki aynı derse katılabilme hakkı kazanmak amacıyla kullanılabilir.

7. Öğretmenlerin özellikle de kadın öğretmenlerin seçmeli dersler hakkındaki olumsuz düşüncelerinin nedeni araştırılmalıdır.

8. Seçmeli derslerde yapılan devamsızlıklar bir üst kurdaki derslere katılmada olumsuz puan olarak değerlendirilmelidir.

9. Seçmeli derslerde her öğrenci için gelişim dosyası tutulmalı, bu dosyalar daha sonra bir sonraki dönemdeki hocalara devredilmelidir.

\section{Kaynakça}

Çelik, Z., Boz, N., Gümüş, S., ve Taştan, F. (2013). Eğitim reformunu izleme raporu. Ankara: Eğitimciler Birliği Sendikası.

Çelik, Z., Yurdakul, S., Bozgeyikli, H. ve Gümüş, S. (2017). Eğitime bakış 2017: İzleme ve değerlendirme raporu. Ankara: Eğitim-Bir-Sen

Cerit, Y., Akgün, N., Yıldız, K., ve Soysal, M. R. (2014). Yeni eğitim sisteminin $(4+4+4)$ uygulanmasında yaşanan sorunlar ve çözüm önerileri (Bolu il örneği). Eğitim Bilimleri Araştırmaları Dergisi, 4(1), 59-82.

Demir, A., ve Ok, A. (1996). Ortadoğu teknik üniversitesindeki öğretim üye ve öğrencilerinin seçmeli dersler hakkındaki görüşleri. Hacettepe Üniversitesi Eğitim Fakültesi Dergisi, 12(12), 121-125.

EARGED. (2008). Seçmeli derslerin seçim kriterlerinin değerlendirilmesi araştırması. Ankara: Milli Eğitim Bakanlığı. file://C:/Users/mdc/Downloads/Documents/secmeli_dersler_aras tirmasi.pdf adresinden alınd. 
Eğitim Reformu Girişimi (2016). Eğitim izleme raporu 2015-16. http://www.egitimreformugirisimi.org/egitim-izleme-raporu2016-17/ adresinden alınmıştır. Erişim tarihi: 19.06.2017

Frank, J. (1976). Complete guide to co-curricular programs and activities for the middle grades. Parker Publishing Company.

Karagözoğlu, N. (2015). Ortaokul 5. sinıflarda tercih edilen seçmeli dersler ve tercih nedenlerinin öğrenci ve veli görüşlerine göre değerlendirilmesi. . Pegem Eğitim ve Öğretim Dergisi, 5(1), 69-94. http://dx.doi.org/10.14527/pegegog.2015.004. adresinden alınd1.

Karasar, N. (2004). Bilimsel Araştırma Yöntemi (13.Bask1). Ankara: Nobel Yayınları.

Kaya, K. (2013). Okul idarecilerinin gözüyle seçmeli ders uygulaması. Okul idarecilerinin gözüyle seçmeli ders uygulaması. Kesintili Oniki Yıllık Zorunlu Ĕgitim Modelinde Seçmeli Dersler Sempozyumu Bildiriler Kitabı, Yüzüncü Yıl Üniversitesi Yayınları, 40-46.

Kutlu, B. S., Abalı, Y. A., ve Eren, T. (2012). Çok ölçütlü karar verme yöntemleri ile seçmeli ders seçimi. Kırıkkale Üniversitesi Sosyal Bilimler Dergisi, 2(2), 5-25.

MEB, Meb Mevzuat. Milli Eğitim Bakanlığı: http://mevzuat.meb.gov.tr/html/temkanun_0/temelkanun_0.html adresinden alınd1.. Erişim tarihi: 25.09.2017.

MEB-TTKB, Milli Eğitim Bakanlığı. Talim Terbiye Kurulu Başkanlığı : http://ttkb.meb.gov.tr/www/haftalık-ders-cizelgeleri/kategori/7 adresinden alındı. Erişim tarihi: 22.09.2017.

Milli Eğitim Bakanlığı Kayseri İl Milli Eğitim Müdürlüğü (t.y). 2016-2017 yılı istatistikler kılavuzu. http://kayseri.meb.gov.tr/www/20162017-egitim-ogretim-yili-kayseri-milli-egitimistatistikleri/icerik/1202 Erişim tarihi: 19.06.2017.

Örs, Ç., Erdoğan, H., ve Kipici, K. (2013). Eğitim Yöneticileri bakış açısıyla 12 yıllık kesintili zorunlu eğitim sistemi. Ĭğır Üniversitesi Sosyal Bilimler Dergisi(4), 131-154.

Özgüven, E. (1989). Yükseköğretirnde öğrenci kişilik hizmetleri. yükseköğretimde rehberlik ve psikolojik danışma toplantısı,. Ankara: A.Ü. Eğitim Bilimleri Fakültesi Yayınları, 161.

Pamuk, E., ve Kiraz, Z. (2016). Ortaokullarda okutulan seçmeli ders uygulamalarında okul yöneticilerinin karşılaştıkları problemler. . 
Abant İzet Baysal Üniversitesi Ĕ̆itim Fakültesi Dergisi, 16(3), 9771003.

Sağır, M. (2015). Eğitim ve Okul sistemindeki son dönem politika değişimlerine ilişkin okul yöneticilerinin görüşlerinin incelenmesi. Turkish Studies-International Periodical for the Languages, Literature and History of Turkish or Turkic, 10(11), 12971310.

Taş, B. S. (2004). Seçmeli ders programlarımı öğretmen ve öğrenci görüşleri doğrultusunda değgrlendirilmesi. Yayımlanmamış yüksek lisans tezi. Çukurova Üniversitesi, Adana.

Tezcan, H. G. (2008). Üniversite öğrencilerinin seçmeli ders tercihlerine etki eden faktörlerin araştırıması. Gazi Üniversitesi, Gazi Eğitim Fakültesi Dergisi, 28(1), 1-17.

Uysal, B. (2015). Ortaokul seçmeli ders uygulamasının okul yöneticisi, öğretmen ve öğrenci görüşlerine göre değerlendirilmesi. Yayımlanmamış Yüksek Lisans Tezi. Ankara Üniversitesi, Ankara.

Ülgen, G. (1992). İlköğretim okullarının 6, 7, 8. sınıflarında seçmeli dersler. Hacettepe Üniversitesi Eğitim Fakültesi Dergisi, 8(8), 107114.

\section{Kaynakça Bilgisi / Citation Information}

Durmuşçelebi, M. ve Mertoğlu, B. (2018). Ortaokul öğrencilerinin eğitiminde seçmeli derslerin yeri. OPUS - Uluslararası Toplum Araştırmaları Dergisi, 8(Gençlik Araştırmaları Özel Sayısı), 170-211. 